Review Article

\title{
Pharmacologic Activities of Plant-Derived Natural Products on Respiratory Diseases and Inflammations
}

\author{
Deepak Timalsina $(\mathbb{D}$, Krishna Prasad Pokhrel $(\mathbb{D}$, and Deepti Bhusal \\ Central Department of Chemistry, Tribhuvan University, Kirtipur, Kathmandu 44618, Nepal \\ Correspondence should be addressed to Deepak Timalsina; geniusdipu5@gmail.com
}

Received 9 July 2021; Accepted 20 September 2021; Published 4 October 2021

Academic Editor: Kazim Husain

Copyright (c) 2021 Deepak Timalsina et al. This is an open access article distributed under the Creative Commons Attribution License, which permits unrestricted use, distribution, and reproduction in any medium, provided the original work is properly cited.

\begin{abstract}
Respiratory inflammation is caused by an air-mediated disease induced by polluted air, smoke, bacteria, and viruses. The COVID19 pandemic is also a kind of respiratory disease, induced by a virus causing a serious effect on the lungs, bronchioles, and pharynges that results in oxygen deficiency. Extensive research has been conducted to find out the potent natural products that help to prevent, treat, and manage respiratory diseases. Traditionally, wider floras were reported to be used, such as Morus alba, Artemisia indica, Azadirachta indica, Calotropis gigantea, but only some of the potent compounds from some of the plants have been scientifically validated. Plant-derived natural products such as colchicine, zingerone, forsythiaside A, mangiferin, glycyrrhizin, curcumin, and many other compounds are found to have a promising effect on treating and managing respiratory inflammation. In this review, current clinically approved drugs along with the efficacy and side effects have been studied. The study also focuses on the traditional uses of medicinal plants on reducing respiratory complications and their bioactive phytoconstituents. The pharmacological evidence of lowering respiratory complications by plant-derived natural products has been critically studied with detailed mechanism and action. However, the scientific validation of such compounds requires clinical study and evidence on animal and human models to replace modern commercial medicine.
\end{abstract}

\section{Introduction}

Respiratory inflammatory disorders comprise several airmediated diseases such as chronic bronchitis, pulmonary diseases, and asthma. Chronic obstructive pulmonary disease (COPD) is a lung inflammatory disease that is the $5^{\text {th }}$ leading cause of death worldwide [1]. Respiratory inflammation is mainly caused by airway disease, characterized by several complications such as coughing, sneezing, and shortness of breath [2]. The disease can act on both upper and lower airways and worsens the other diseases including rhinosinusitis and tightness of the chest [3]. There are multiple problems associated with respiratory inflammation. The upper inflammation is associated with the common cold, pharyngitis, sinusitis, laryngotracheitis, and epiglottitis, and lower inflammation is associated with bronchiolitis, bronchitis, and pneumonia [4]. The inflammation is also induced by a respiratory virus that infects the epithelial lining of the airways and replicates in it [5]. This inflammation normally leads to type 1 inflammation. Inflammation in the healthy airway results in the activation of antiviral state and clearance of viral infection $[6,7]$, but in chronically inflamed airways, the response against the virus may impair resulting in sustained inflammation $[8,9]$ and reduced ability of viral clearance $[10,11]$. The acute exacerbations may be triggered by several allergens, pollutants, cold and dry air, smoke inhalations, and several pathogenic bacteria in the airways [12]. Asthma is one of the chronic respiratory diseases marked by reversible airway constriction, eosinophil infiltration, increased mucus production, and nonspecific hyperresponsiveness of the airways [13].

There are several treatment methods for reducing complications of respiratory inflammation that include oxygen therapy, steam therapy, draining mucus from the lungs, and taking antihistamines and bronchodilators. Several steroidal and nonsteroidal drugs are used to lessen down inflammation. Inhaled corticosteroids (ICS) in combination with long-acting beta-agonist (LABA) are recommended in 
many countries. Long-acting bronchodilators such as salmeterol and formoterol can be used in asthma according to the rate of intrinsic activity. Some ultraclass drugs such as $\beta-2$ agents [14], olodaterol [15], vilanterol [16], carmoterol, PF610355, LAS100977, and AZD3199 are recommended for therapy against respiratory diseases. Many of the plants such as Adiantum capillus-veneris, Aegle marmelos, Aerva javanica var. javanica [17], Albizia lebbeck, Alhagi maurorum, and Alhagi maurorum were used in respiratory disorders by traditional healers and indigenous people [18]. There are many plant-derived compounds of different classes such as alkaloids, flavonoids, glycosides, lignans, polyphenols, and saponins that are studied for their activities against respiratory disease and inflammation. Some compounds like mangiferin, zingerone, glycyrrhizin, piperine, and forsythiaside A are promising and have evidence of positive results in an animal study. Despite the promising effect of plant-derived natural products, the extensive study of clinical evidence and their toxicological aspect is still lacking. Only some of the compounds have been isolated, and a lesser number of experiments have been done in the human model. This review is aimed at collecting and analyzing the traditional approach, reported natural products, and their pharmacological evidence on respiratory diseases and inflammations with sufficient research gaps and recommendations.

\section{Methodology}

The information on respiratory diseases and inflammations had been retrieved from an extensive literature survey. Systematic literature had been searched by using an online database such as Google Scholar, PubMed, SciFinder, ScienceDirect, Mendeley, and Scopus. Literatures were searched in the online database using keywords such as "Respiratory inflammation", "Ethnomedicine and respiratory diseases", "Bioactive compounds and respiratory disease", and "Respiratory drugs". The cross-referenced articles were also retrieved. Various books, thesis, proceedings, and news articles were secondary sources of information.

\section{Current Clinical Practice and Approved Drugs}

Respiratory inflammatory diseases like asthma and chronic obstructive pulmonary disease (COPD) are usually treated with effective modern medicines of different classes. Nonsteroidal anti-inflammatory drugs (NSAIDs) is a class of drug that has been used efficiently and commonly in the inhibition of the cyclooxygenase enzyme. The past study showed the prescription of triple therapy for the treatment of pulmonary diseases [19] which suggested the use of a long-acting beta-agonist (LABA) and long-acting muscarinic antagonist (LAMA) in combination with inhaled corticosteroid (ICS) [20]. There is a major development in treating COPD and asthma by the ICS-LABA-LAMA therapy. The most common prescriptions nowadays are LABA and ICS discovered by the physician in Europe [21]. The common uses of $22 \%$ ICS and 39\% bronchodilators are for lower symptoms and $46 \%$ ICS and $67 \%$ bronchodilators are for greater symptoms.
Due to the limited effect of this medication, a trial for triple therapy is tried in every patient [22]. NSAIDs, bronchodilators $\left(\beta_{2}\right.$-adrenoreceptor (AR) agonists, muscarinic receptor antagonists, and xanthines) [23], and corticosteroids [24] are a highly recommended initial therapy for most patients individually or in combination with one of the other classes [25]. Nonselective COX inhibitors for reducing respiratory inflammation include aspirin, ibuprofen, naproxen, and diclofenac, and selective COX inhibitors include celecoxib, lumiracoxib, etoricoxib, valdecoxib, and rofecoxib [26]. Among different bronchodilators, fast-acting and shortacting albuterol, terbutaline, and fenoterol are efficiently used, yet long-acting agonists salmeterol and formoterol are best for therapy. Some drugs of class ultra-long-acting $\beta_{2}$ agents indacaterol [14], olodaterol [15], vilanterol [16], carmoterol, PF-610355, LAS100977, AZD3199, etc. had been prescribed for achieving one dose daily [27]. The use of a combination of drugs using $\beta_{2}$ long-acting and antimuscarinic controls the transforming growth factor (TGF)- $\beta^{1}$ mediated inflammation in COPD. The novel antimuscarinic agents such as QAT370, glycopyrronium (NVA237), aclidinium, GSK573719, CHF5407, BEA2180BR, TD4208, PF452297, RBx343E48F0, trospium, and dexpirronium are generally used at a high dose for a prolonged duration of action [27]. Anti-inflammatory and bronchodilator action of xanthines such as bamiphylline, enprofylline, isbufylline, and doxophylline is reported to be used in the treatment of asthma and COPD. The safer use of xanthines inhibits the family of phosphodiesterase (PDE3 and 4) enzymes for long-term improvement in lung function [28]. Different NSAIDs like ibuprofen are used in COVID-19 infection, but there is a lack of studies that shows the association between the use of NSAID and COVID-19 severity. Currently, known antiviral agents like lopinavir/ritonavir and remdesivir have a high affinity to the viral enzyme and could inhibit the synthesis of the nitrogenous base resulting in the inhibition of RNA replication through premature termination of the virus [29]. Anti-inflammatory drugs like corticosteroids had a role in the significant reduction of in-hospital mortality by COVID-19 [30]. During this pandemic of COVID-19, several pulmonary complications from this disease were reported such as mucormycosis and pulmonary aspergillosis [31]. These are life-threatening fungal infections and have a role in complicating pulmonary conditions like asthma, bronchiectasis, and COPD. These pulmonary infections are found to attack patients with low immunity. Many researchers and health personnel assumed it was due to the excessive use of corticosteroids. Corticosteroids are used for the treatment of COVID-19 patients which in turn reduces immunity due to which the patients are prone to be infected by mucormycosis and aspergillosis [32]. Losmapimod, p38, a subfamily of mitogen-activated protein kinase (MAPK) inhibitor, is widely studied and used safely as a single IV infusion of 1 to $3 \mathrm{mg}$ doses. There are no severe effects reported except headache, nausea, and fatigue ([33]). Various reports suggested that this can be appropriate in treating COVID-19 patients [34]. The recent trial in the mouse model supported a similar result [35]. Besides this, p38 was able to cause a pathogenic role in asthma and COPD. The 
adverse factors causing these diseases activate the p38 which in turn amplifies lung inflammation. The clinically trialed anti-interleukins like benralizumab, daclizumab, reslizumab, MEDI-528, mepolizumab, and lebrikizumab showed improvement in patients by decreasing eosinophils and other exacerbations [36]. The clinical trial of benralizumab revealed the effects in reducing eosinophil and improved lung function but with some headache and nausea effects [37]. Number of trials had been conducted for treating upper airway disorders such as allergic rhinitis, nasal polyps, and chronic rhinosinusitis for which several therapeutics such as omalizumab, mepolizumab, dupilumab, a monoclonal antibody targeted toward IgE, an antiIL-5 agent, anti-IL-4, and IL-3 had been used. The outcomes of the trials were positive [38].

Several other modern drugs have been discovered and synthesized in the laboratory with promising results. However, the success of low-molecular-weight drugs remains low as respiratory inflammation diseases are complex in etiology. The critical target molecule that is directly associated with the disease process has not been found yet. The plant can be the potent source of such medicine as plants have diverse compositions and complex molecular associations. Recently available techniques are effective but associated with several complications such as cost, demand, and availability. Thus, a new kind of efficient and easily available therapeutics should be introduced for developing new kinds of drugs against respiratory inflammation.

\section{Ethnomedicinal Practice on Treating Respiratory Complications}

Several plants were reported to be used for their antiinflammatory properties that can be used in acute as well as chronic bronchitis. Ethnomedicinally, the number of plants had been reported based on indigenous knowledge of people and the practice of traditional healers. Plants such as Morus alba [39], Dicliptera bupleuroides, Adiantum capillus-veneris, Trichodesma indicum, and Viburnum grandiflorum were reported to be traditionally used in Pakistan and Korea for treating whooping cough and the common cold. The decoction of leaves of Dicliptera bupleuroides was known to apply externally in the throat for managing the cough by the local people of Kashmir of Pakistan [40]. The milky latex and flower paste of Calotropis gigantea found in the Terai forest of western Nepal were reported to be taken orally for the management of cough and bronchitis [41]. Some of the reported plants acting against respiratory disorders, based on traditional knowledge and practices, have been listed in Table 1.

\section{Plant-Derived Compounds on Treating Respiratory Complications}

The number of compounds (Table 2) derived from plants was reported for the prominent therapeutics against respiratory inflammation. The flavonoids such as kuwanone E, kuwanone G, and norartocarpanone from Morus alba [61], sakuranetin from Baccharis retusa [62], and pinocembrin (5,7-dihydroxyflavanone) from Alpinia katsumadai have been reported to act against respiratory inflammation. The polyphenols such as curcumin (1,7-bis(4-hydroxy-3-methoxyphenyl)-1,6-heptadiene-3,5-dione) from Curcuma longa rhizome[63, 64], resveratrol from grapes [65], and luteolin from Lonicera japonica [66] were reported to act against respiratory inflammation. The other classes of plantderived compounds such as alkaloids [67], coumarins [68], and triterpenoids, saponins, and steroids [69-72] were reported to be effective against several kinds of inflammations. Colchicine is a plant alkaloid derivative that could be used as a substitute for commercial colchicine. Colchicine concentrations differ from organ to organ, and colchicine content was demonstrated to be influenced by plant age, seasonality, and location. Colchicine was found to reduce neutrophil elastase concentration in bronchoalveolar lavage fluid in ex-smokers with COPD [73]. Some of the structures of the potent bioactive compounds are given in Figures 1 and 2 .

The reported compounds are mostly tested in mice invivo, and the inflammation is mainly induced by LPS. The study on the human model and its clinical evidence is still lacking. The possible therapeutics from this promising compound is yet to be studied. The compounds with lower doses and higher activities should be taken into the clinical trial in a sample population.

\section{Mechanism of Action of Plant-Based Natural Product}

The lung inflammation involves the activation of inflammatory cells such as eosinophils, lymphocytes, macrophages, and neutrophils, which serve as the source of different inflammatory mediators such as tumor necrosis factor (TNF- $\alpha$ ), interleukins (IL-4, IL-1 $\beta$, IL-6, and IL-5), histamine, prostaglandins, nitric oxide, and leukotriene. The release of these inflammatory mediators causes several abnormalities in the lungs and their function [156]. Natural products target the epithelial-mesenchymal transition (EMT), oxidative stress, fibroblast activation, inflammatory injury, metabolic regulation, and extracellular matrix accumulation. The basic mechanisms involved are the NF- $\kappa \mathrm{B}$, TGF- $\beta 1 /$ Smad, PI3K/Akt, p38 MAPK, Nrf2-Nox4, and AMPK signaling pathways [157]. The plant flavonoid such as eriodictyol was reported to serve as the anti-inflammatory agent in the lungs which regulates the Nrf2 pathway and inhibited the expression of inflammatory cytokines IL-6, TNF- $\alpha$, IL- $1 \beta$, etc. [86]. The flavonoids kaempferol and luteolin reduced the LPS-induced activation of the MAPK and NF$\kappa \mathrm{B}$ pathways and also reported to inhibit the ICAM- 1, TNF- $\alpha$, SOD, KC, and neutrophil inflammation. This compound was also found to involve in the reduction of the activity of superoxide dismutase and catalase and further reduces the lipid peroxidation and oxidative damage in the lung tissue $[158,159]$. A natural product such as sakuranetin was also reported to reduce the TNF- $\alpha$, eosinophils, M-CSF, RANTES, IL-5, and IL- $1 \beta$ and inhibited the NF- $\kappa$ B, MMP-12-positive, and MMP-9-positive cells and also increased the TIMP-1 expression to serve as anti-inflammatory activities in the lungs of 


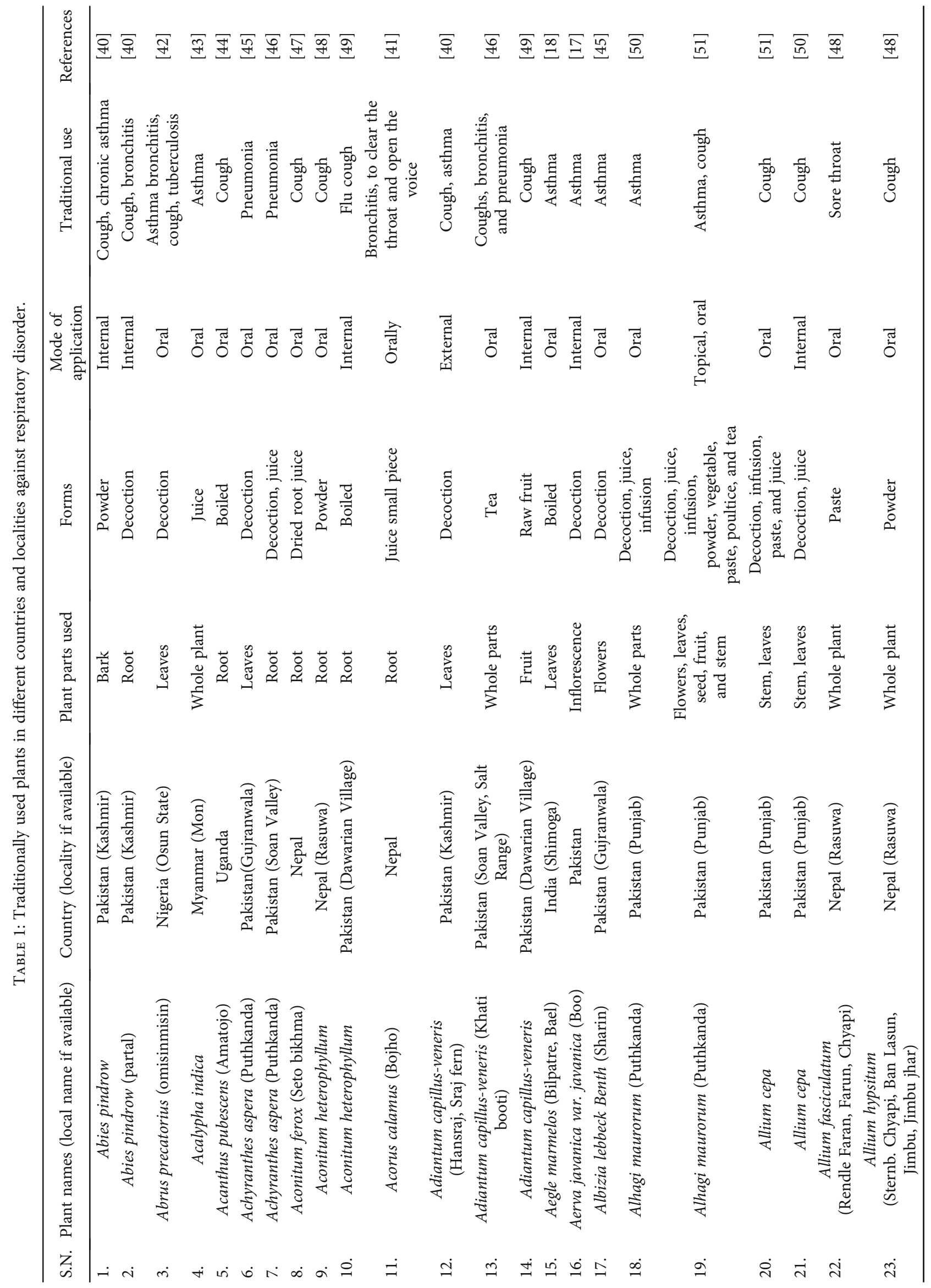




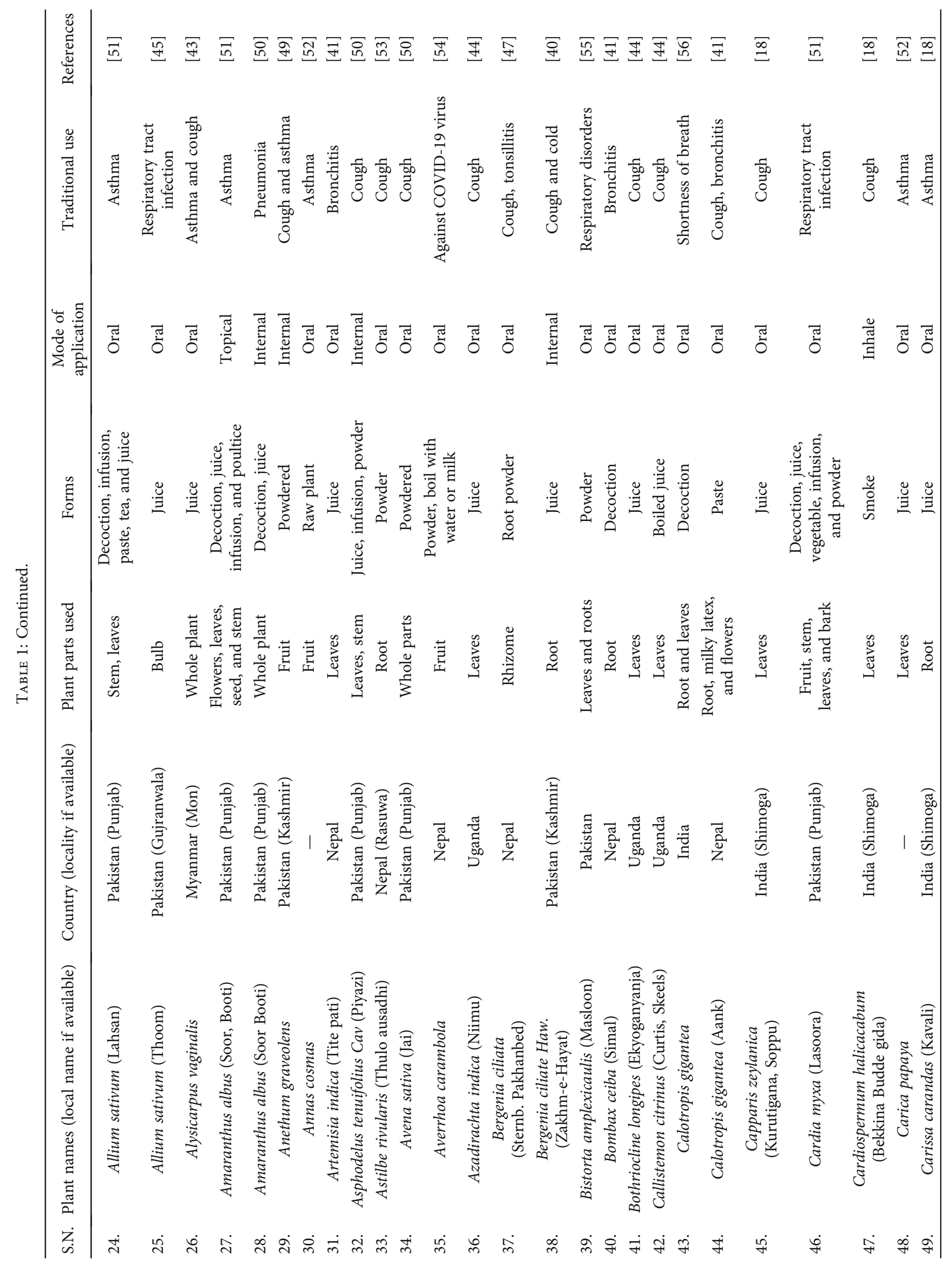




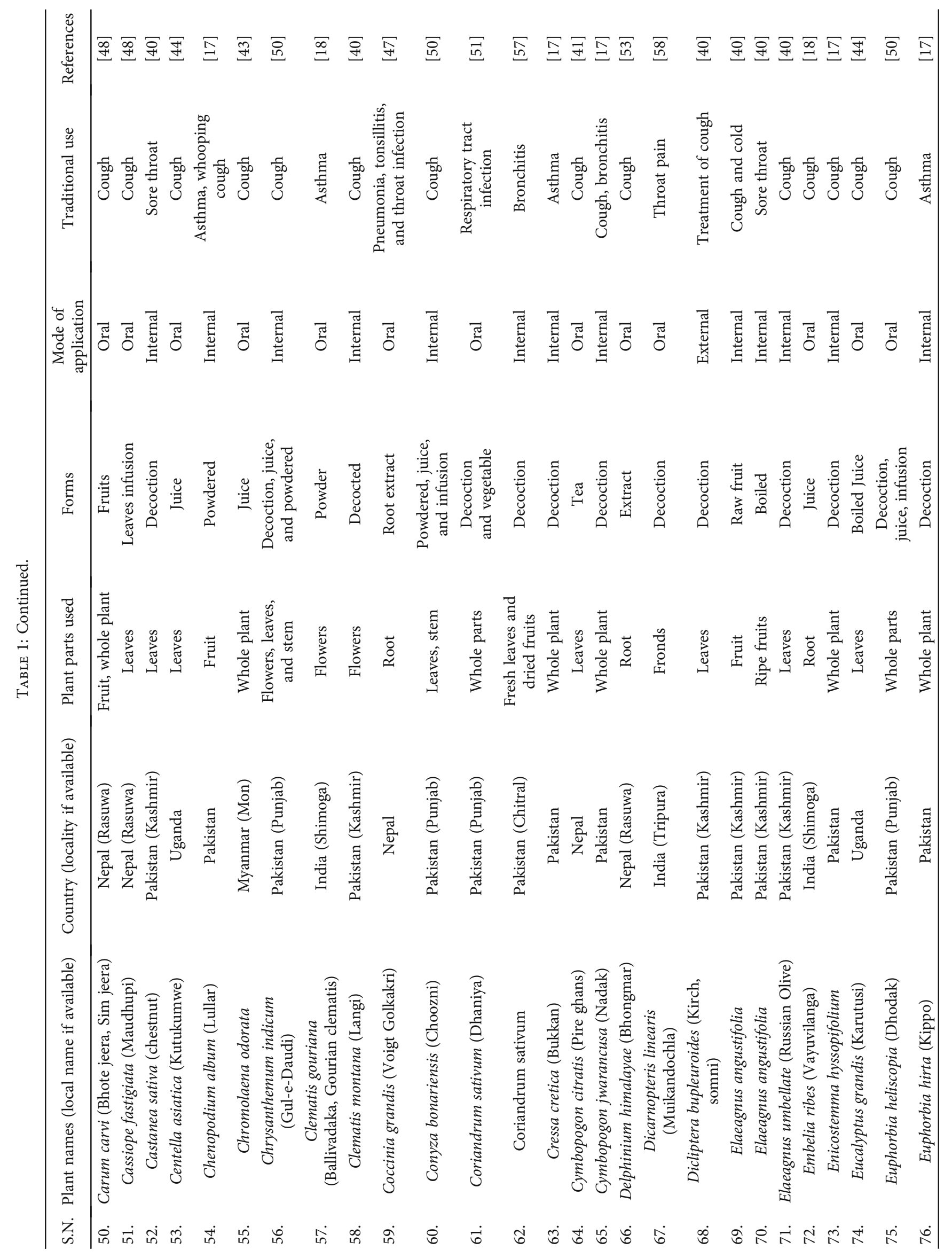




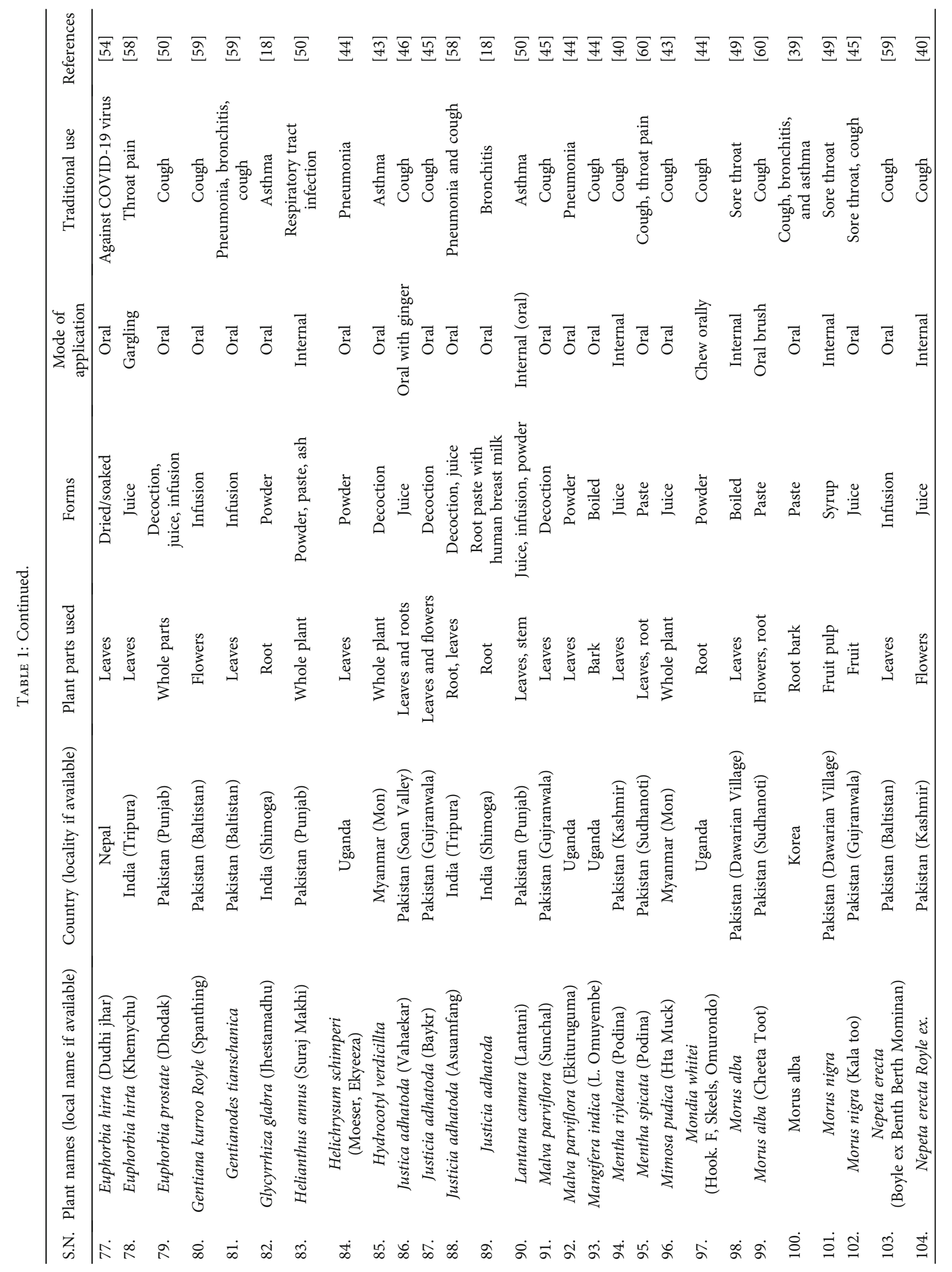




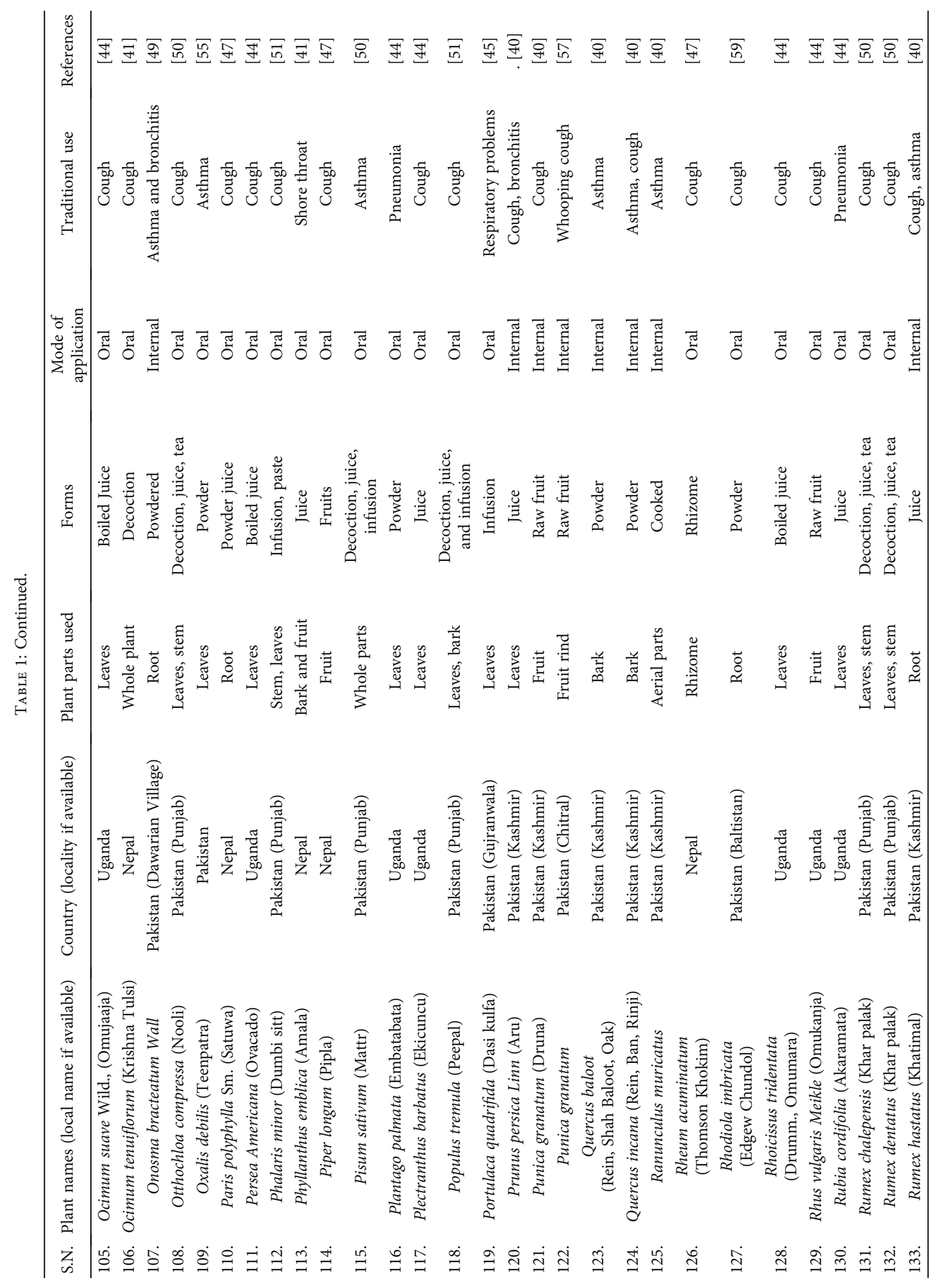




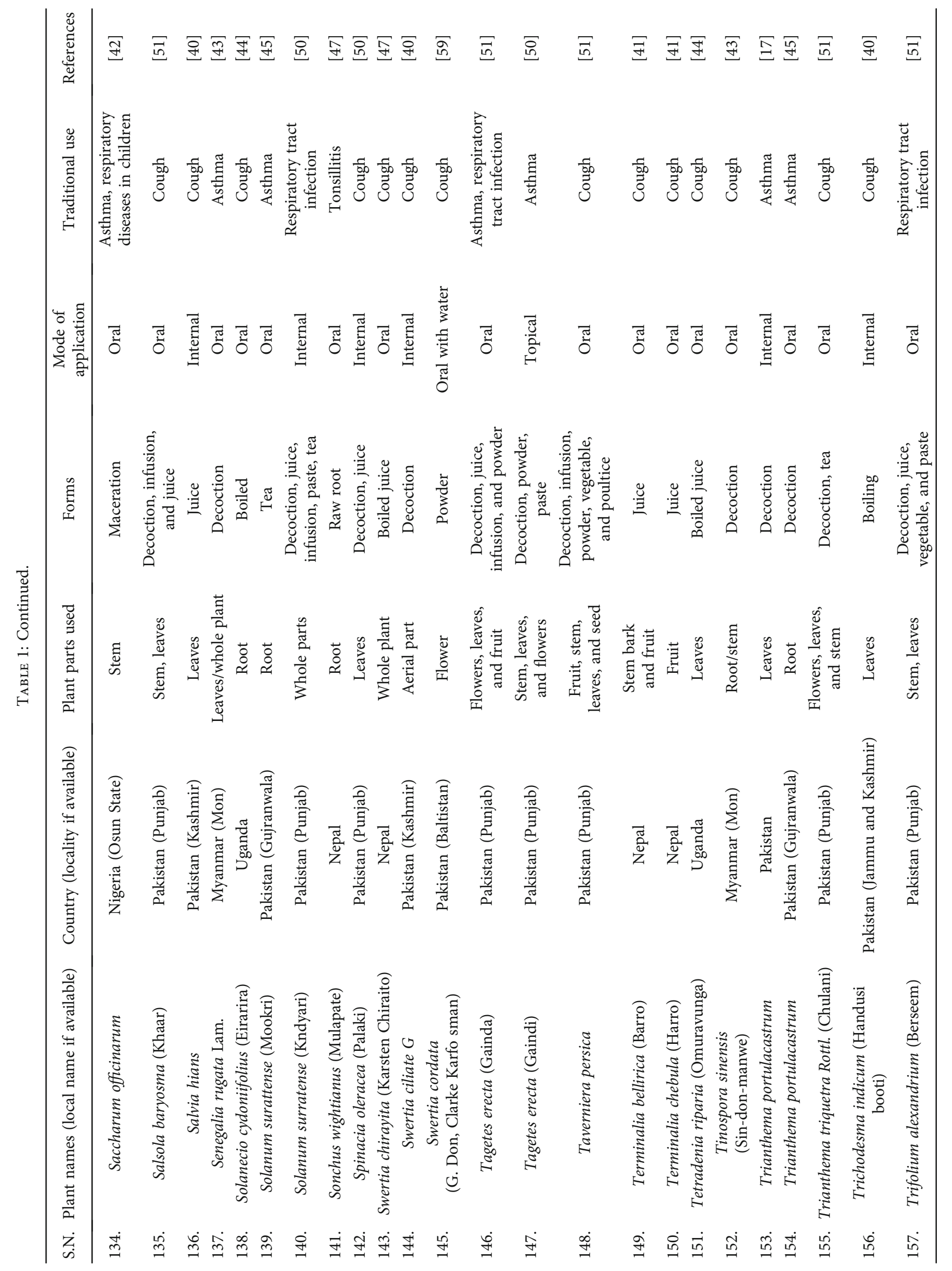




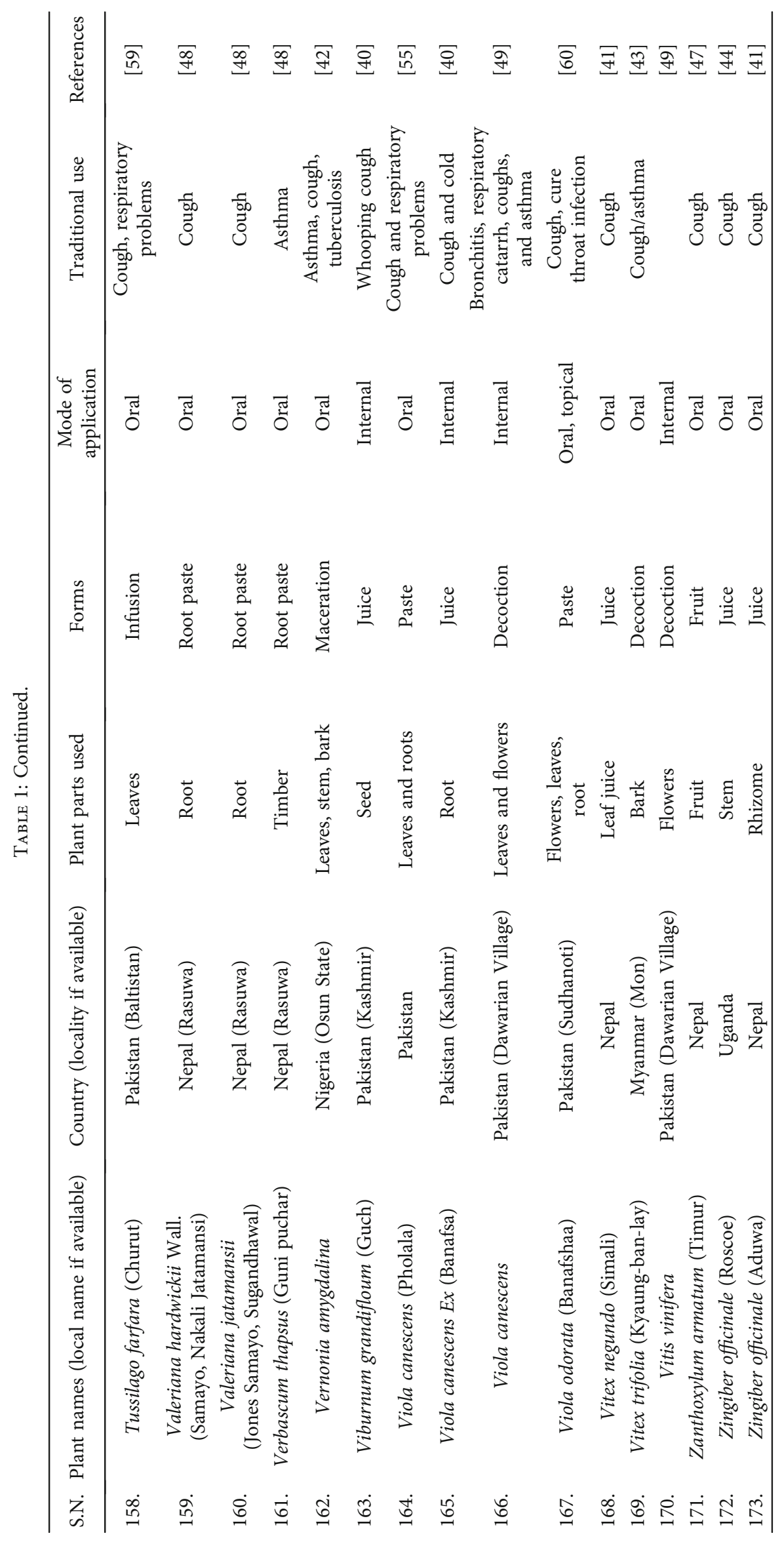


TABLE 2: Plant-derived compounds associated with respiratory inflammation.

\begin{tabular}{|c|c|c|c|c|c|}
\hline S.N. & Constituents & Plant origin & Doses & Inflammagen used & References \\
\hline \multicolumn{6}{|c|}{ Alkaloids } \\
\hline 1. & Warifteine & Cissampelos sympodialis & $2 \mathrm{mg} / \mathrm{kg}$ & OVA-induced & {$[74]$} \\
\hline 2. & Colchicine & Colchicum autumnale & $0.25-0.5 \mathrm{mg} / \mathrm{kg}$ & $\begin{array}{c}\text { Idiopathetic } \\
\text { pulmonary fibrosis }\end{array}$ & {$[73]$} \\
\hline 3. & Imperialine & Fritillaria cirrhosa & $3.5-7 \mathrm{mg} / \mathrm{kg}$ & Cigarette smoke or LPS & {$[75]$} \\
\hline 4. & Piperine & Piper longum & $2.25-4.5 \mathrm{mg} / \mathrm{kg}$ & Ovalbumin & {$[67]$} \\
\hline 5. & Cepharanthine & Stephania cepharantha & $5 \mathrm{mg} / \mathrm{kg}$ & LPS & [76] \\
\hline 6. & Nimbandiol & Azadirachta indica & (in silico) & - & [77] \\
\hline 7. & Vasicine & & & & \\
\hline 8. & Vasicinone & Peganum harmala & $45 \mathrm{mg} / \mathrm{kg}$ & $\begin{array}{c}\text { Ammonia liquor, capsaicin, } \\
\text { and citric acid }\end{array}$ & {$[78]$} \\
\hline 9. & Deoxyvasicine & & & & \\
\hline \multicolumn{6}{|c|}{ Cannabinoids } \\
\hline 10. & Cannabidiol & Cannabis sativa & $20 \mathrm{mg} / \mathrm{kg}$ & LPS & {$[79,80]$} \\
\hline \multicolumn{6}{|c|}{ Flavonoids } \\
\hline 11. & $\begin{array}{c}\text { Pinocembrin } \\
\text { (5,7-dihydroxyflavanone) }\end{array}$ & Alpinia katsumadai & $20-50 \mathrm{mg} / \mathrm{kg}$ & LPS & {$[81]$} \\
\hline 12. & Naringenin & Prunus persica & $15-100 \mathrm{mg} / \mathrm{kg}$ & LPS, Staphylococcus aureus & {$[82,83]$} \\
\hline 13. & Naringenin & Vitis vinifera & $100-200 \mathrm{mg} / \mathrm{kg}$ & Radiations ( $\gamma$-ray) & {$[84]$} \\
\hline 14. & Alpinetin & Alpinia katsumadai & $50 \mathrm{mg} / \mathrm{kg}$ & LPS & {$[85]$} \\
\hline 15. & Eriodictyol & Dracocephalum rupestre & $30 \mathrm{mg} / \mathrm{kg}$ & LPS & {$[86]$} \\
\hline 16. & Licorice flavonoid (liquiritin) & Glycyrrhiza uralensis & $30 \mathrm{mg} / \mathrm{kg}$ & LPS & {$[87]$} \\
\hline 17. & Isoliquiritigenin (ILG) & Glycyrrhiza glabra & $10-30 \mathrm{mg} / \mathrm{kg}$ & Cigarette smoke & {$[88]$} \\
\hline 18. & Baicalin & & & & \\
\hline 19. & Oroxylin A & & & Cigarette smoke-induced & \\
\hline 20. & Wogonin & Scutellaria baicalensis & $20-80 \mathrm{mg} / \mathrm{kg}$ & $\begin{array}{l}\text { (rat model)/ovalbumin } \\
\text { (OVA)/influenza H1N1 }\end{array}$ & {$[89-91]$} \\
\hline 21. & Chrysin & & & & \\
\hline 22. & Moracins & Morus alba & $20-60 \mathrm{mg} / \mathrm{kg}$ & LPS & [92] \\
\hline 23. & Sakuranetin & Baccharis retusa & $20 \mathrm{mg} / \mathrm{kg}$ & Elastase-induced emphysema & {$[62]$} \\
\hline 24. & Schaftoside & Eleusine indica & $0.4 \mathrm{mg} / \mathrm{kg}$ & LPS & [93] \\
\hline 25. & Kuwanone E & & & & \\
\hline 26. & Kuwanone G & Morus alba & $200-400 \mathrm{mg} / \mathrm{kg}$ & LPS & {$[61]$} \\
\hline 27. & Norartocarpanone & & & & \\
\hline 28. & Luteolin & Mosla chinensis & $288-576 \mathrm{mg} / \mathrm{kg}$ & LPS & {$[94]$} \\
\hline 29. & Mosla scabra flavonoids & Mosla scabra & $30-90 \mathrm{mg} / \mathrm{kg}$ & LPS & [95-97] \\
\hline 30. & Apigenin & Allium cepa, Citrus $X$ sinensis & $10-20 \mathrm{mg} / \mathrm{kg}$ & LPS & [98] \\
\hline 31. & Myricetin & Abelmoschus moschatus & $100 \mathrm{mg} / \mathrm{kg}$ & Bleomycin & [99] \\
\hline 32. & Icariin & Epimedium brevicornu & - & Ova-induced & {$[100]$} \\
\hline 33. & Fisetin & Cucurbita pepo & $1-3 \mathrm{mg} / \mathrm{kg}$ & Ova-induced & {$[101,102]$} \\
\hline \multicolumn{6}{|c|}{ Glycosides } \\
\hline 34. & Vitexin & Leaf of Crataegus & $10 \mathrm{mg} / \mathrm{kg}$ & LPS & [103] \\
\hline 35. & Hyperin & Houttuynia cordata & $50-200 \mathrm{mg} / \mathrm{kg}$ & Influenza virus $\mathrm{H} 1 \mathrm{~N} 1$ & {$[104]$} \\
\hline 36. & Quercitrin & Houttuynia cordata & $100 \mathrm{mg} / \mathrm{kg}$ & LPS/influenza virus H1N1 & {$[104,105]$} \\
\hline 37. & Picroside II & Picrorhiza scrophulariflora & $0.5-1 \mathrm{mg} / \mathrm{kg}$ & LPS & {$[106]$} \\
\hline \multicolumn{6}{|c|}{ Lignans } \\
\hline 38. & Magnolol & Magnolia officinalis & $5-20 \mathrm{mg} / \mathrm{kg}$ & LPS & {$[107]$} \\
\hline 39. & Phillyrin & Forsythia suspensa & $10-20 \mathrm{mg} / \mathrm{kg}$ & LPS & {$[108]$} \\
\hline 40. & Columbianadin & Angelica decursiva & $20-60 \mathrm{mg} / \mathrm{kg}$ & LPS & {$[68]$} \\
\hline
\end{tabular}


TABle 2: Continued.

\begin{tabular}{|c|c|c|c|c|c|}
\hline S.N. & Constituents & Plant origin & Doses & Inflammagen used & References \\
\hline 41. & Schisantherin A & Schisandra sphenanthera & $40 \mathrm{mg} / \mathrm{kg}$ & LPS & [109] \\
\hline 42. & Schisantherin B & Schisandra chinensis & $15-60 \mathrm{mg} / \mathrm{kg}$ & OVA-induced & {$[110]$} \\
\hline \multicolumn{6}{|c|}{ Macromolecular polymer } \\
\hline 43. & Lipopolysaccharides & Houttuynia cordata & $40-160 \mathrm{mg} / \mathrm{kg}$ & LPS & [111] \\
\hline 44. & Polysaccharides & Houttuynia cordata & $20-40 \mathrm{mg} / \mathrm{kg}$ & $\begin{array}{l}\text { Influenza A virus } \\
\text { (IAV) H1N1 }\end{array}$ & [112] \\
\hline \multicolumn{6}{|c|}{ Polyphenols } \\
\hline 45. & Resveratrol & & $50 \mathrm{mg} / \mathrm{kg}$ & OVA-induced allergy & {$[65,113]$} \\
\hline 46. & Luteolin & Lonicera japonica & $18-70 \mu \mathrm{mol} / \mathrm{kg}$ & LPS & {$[66]$} \\
\hline 47. & Curcumin & Curcuma longa & $150 \mathrm{mg} / \mathrm{kg}$ & Klebsiella pneumoniae & {$[63,64]$} \\
\hline \multicolumn{6}{|c|}{$\begin{array}{l}\text { Saponins } \\
\text { San }\end{array}$} \\
\hline 48. & Lugrandoside & $\begin{array}{l}\text { Digitalis lutea and } \\
\text { Digitalis grandiflora }\end{array}$ & $10-30 \mathrm{mg} / \mathrm{kg}$ & LPS & {$[114]$} \\
\hline 49. & Ginsenosides & Panax ginseng & $20 \mathrm{mg} / \mathrm{kg}$ & LPS & [115] \\
\hline 50. & Methyl protodioscin & Asparagus cochinchinensis & $30-60 \mathrm{mg} / \mathrm{kg}$ & LPS & {$[116]$} \\
\hline 51. & Glycyrrhizin & Glycyrrhiza glabra & $2.5-20 \mathrm{mg} / \mathrm{kg}$ & OVA-induced allergy & {$[69,70]$} \\
\hline 52. & Mogroside V & Momordica grosvenori & $2.5-10 \mathrm{mg} / \mathrm{kg}$ & LPS & {$[117]$} \\
\hline 53. & Hederacoside C & Hedera helix & $50 \mathrm{mg} / \mathrm{kg}$ & S. aureus & {$[118,119]$} \\
\hline 54. & Platycodin D & Platycodon grandiflorum & $50-100 \mathrm{mg} / \mathrm{kg}$ & LPS & [120] \\
\hline 55. & Rhodiocyanoside A & Rhodiola rosea & $200-800 \mathrm{mg} / \mathrm{kg}$ & Cigratte smoke and LPS & [121] \\
\hline 56. & Stevioside & Stevia rebaudiana & $12.5-50 \mathrm{mg} / \mathrm{kg}$ & LPS & {$[122]$} \\
\hline 57. & Hesperidine & Mentha piperita & (in silico) & - & {$[123]$} \\
\hline \multicolumn{6}{|c|}{ Terpenoids } \\
\hline 58. & Patchouli alcohol & Pogostemon cablin & $10-40 \mathrm{mg} / \mathrm{kg}$ & LPS & {$[124]$} \\
\hline 59. & Pogostone & Pogostemon cablin & $10-40 \mathrm{mg} / \mathrm{kg}$ & LPS & {$[125]$} \\
\hline 60. & Andrographolide & Andrographis paniculata & $0.1-1 \mathrm{mg} / \mathrm{kg}$ & Cigarette smoke (CS) & {$[126-128]$} \\
\hline 61. & Geraniol & $\begin{array}{l}\text { Citrus X lemon, rosa, } \\
\text { Zingiber officinale Rosc., } \\
\text { and Citrus X sinensis }\end{array}$ & $12.5-50 \mathrm{mg} / \mathrm{kg}$ & LPS & {$[129,130]$} \\
\hline 62. & Carvacrol & $\begin{array}{c}\text { Plectranthus amboinicus, } \\
\text { Zataria multiflora }\end{array}$ & $20-80 \mathrm{mg} / \mathrm{kg}$ & LPS & {$[131,132]$} \\
\hline 63. & Isoforskolin & Coleus forskohlii & $5-20 \mathrm{mg} / \mathrm{kg}$ & LPS & [133] \\
\hline 64. & Sclareol & Salvia sclarea & $2.5-10 \mathrm{mg} / \mathrm{kg}$ & LPS & [134] \\
\hline 65. & Triptolide & Tripterygium wilfordii & $5-15 \mu \mathrm{g} / \mathrm{kg}$ & LPS & [135] \\
\hline 66. & Thymoquinone & Nigella sativa & $5-10 \mathrm{mg} / \mathrm{kg}$ & LPS & [136] \\
\hline 67. & Oridonin & Rabdosia rubescens & $20-40 \mathrm{mg} / \mathrm{kg}$ & LPS & [137] \\
\hline 68. & $\beta$-Patchoulene & Pogostemon cablin & $10 \mathrm{mg} / \mathrm{kg}$ & LPS & [138] \\
\hline 69. & Taraxasterol & Taraxacum officinale & $2.5-10 \mathrm{mg} / \mathrm{kg}$ & LPS & [139] \\
\hline 70. & 1,8-Cineol & Eucalyptus globulus & $10^{-4} \mathrm{M}$ & LPS & [113] \\
\hline 71. & Fridelin & Euphorbia nerifolia & $5 \mu \mathrm{g} / \mathrm{mL}$ & COVID-19 & {$[140]$} \\
\hline 72. & Asiatic acid & Centellae asiaticae herba & $25-100 \mathrm{mg} / \mathrm{kg}$ & LPS & {$[141,142]$} \\
\hline \multicolumn{6}{|c|}{ Others } \\
\hline 73. & Mangiferin & Mangifera indica & $0.45-4.5 \mathrm{mg} / \mathrm{kg}$ & LPS & {$[143]$} \\
\hline 74. & Ergosterol & Scleroderma polyrhizum & $25-50 \mathrm{mg} / \mathrm{kg}$ & LPS & {$[144]$} \\
\hline 75. & Crytotanshinone & Salvia miltiorrhiza & $10-40 \mathrm{mg} / \mathrm{kg}$ & LPS & [145] \\
\hline 76. & Prime-O-glucosylcimifugin & Saposhnikovia divaricata & $2.5-10 \mathrm{mg} / \mathrm{kg}$ & LPS & {$[146]$} \\
\hline 77. & Usnic acid & Lichen spp. & $50-100 \mathrm{mg} / \mathrm{kg}$ & LPS & {$[147]$} \\
\hline 78. & Shikonin & Lithospermum erythrorhizon & $12.5-50 \mathrm{mg} / \mathrm{kg}$ & LPS & {$[148,149]$} \\
\hline
\end{tabular}


TABLE 2: Continued.

\begin{tabular}{|c|c|c|c|c|c|}
\hline S.N. & Constituents & Plant origin & Doses & Inflammagen used & References \\
\hline 79. & Linalool & Aromatic plant & $10-40 \mathrm{mg} / \mathrm{kg}$ & Cigarette smoke & {$[150]$} \\
\hline 80. & Zingerone & Zingiber officinale & $10-40 \mathrm{mg} / \mathrm{kg}$ & LPS & {$[151]$} \\
\hline 81. & Paeonol & Paeonia suffruticosa & $10 \mathrm{mg} /$ day & Cigarette smoke (CS) & {$[152]$} \\
\hline 82. & Acteoside & Rehmannia glutinosa & $30-60 \mathrm{mg} / \mathrm{kg}$ & LPS & [153] \\
\hline 83. & Forsythiaside A & Forsythia suspensa & $15-60 \mathrm{mg} / \mathrm{kg}$ & Cigarette smoke & {$[154]$} \\
\hline 84. & Chloroform & Pyrossia lingua & $2378 \mu \mathrm{g} / \mathrm{mL}$ & COVID-19 & [140] \\
\hline 85. & 3,4-Di-O-caffeoylquinic acid & Lonicera japonica & $68.3 \mu \mathrm{M}$ & Virus & {$[155]$} \\
\hline
\end{tabular}
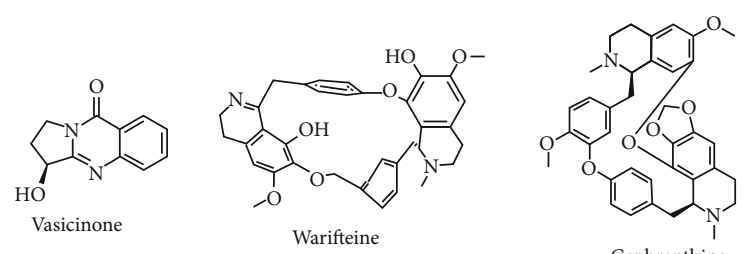

Cephranthine
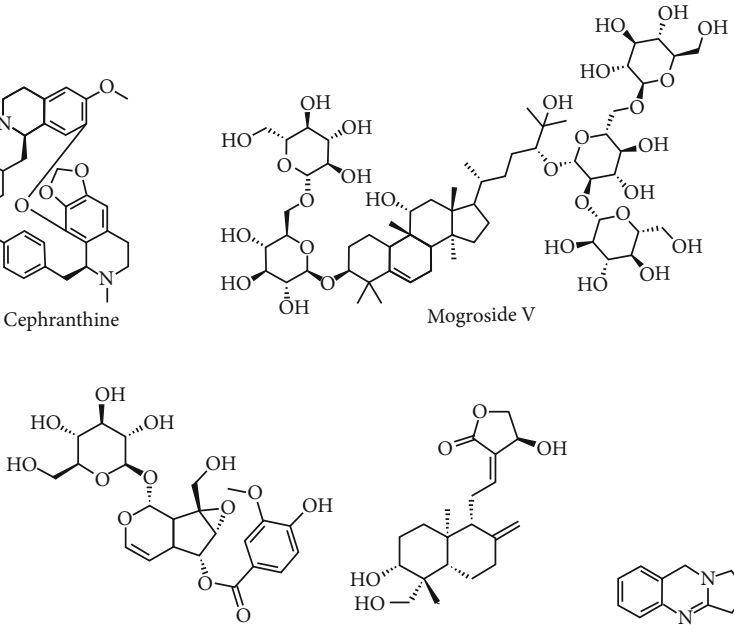

Picroside II
Colchicine

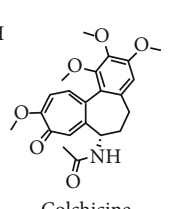

(n)
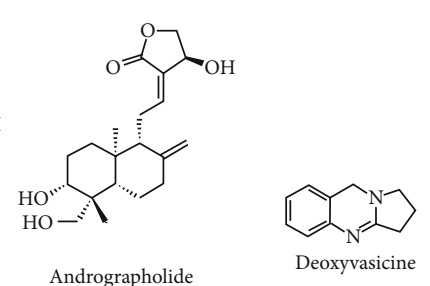

Luteolin
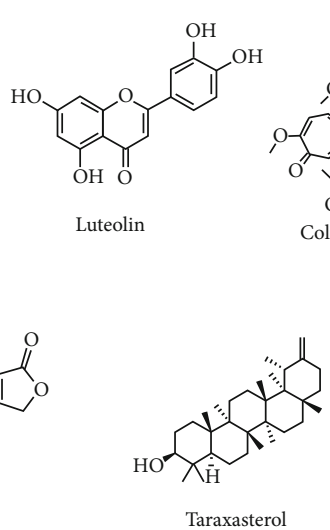

Taraxastero
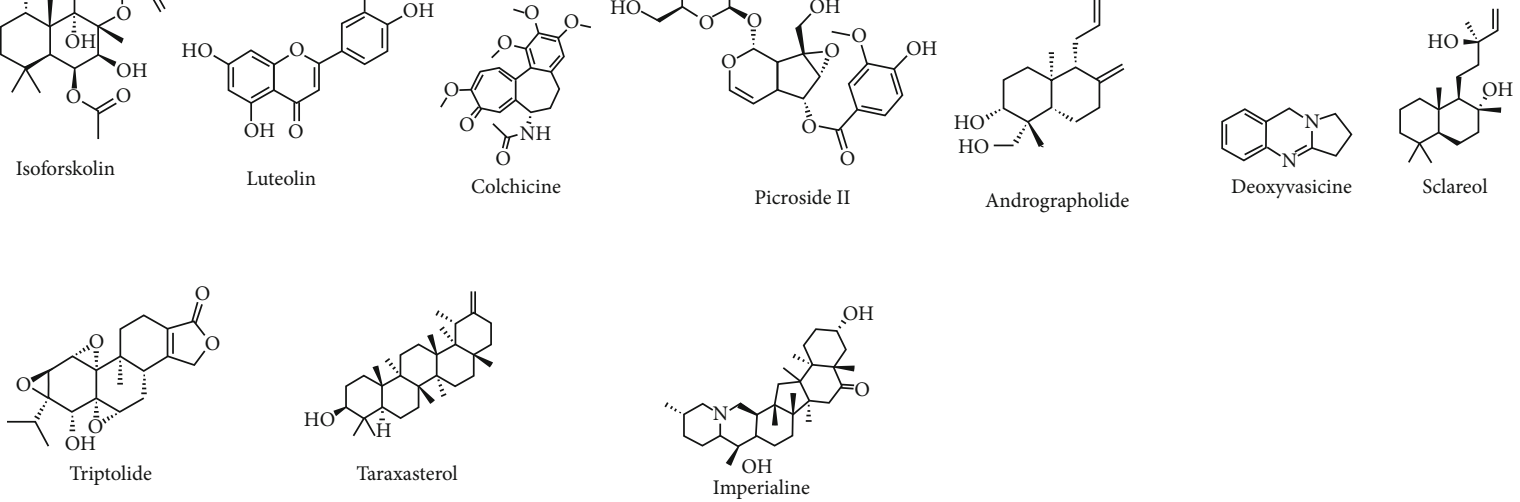

FIGURE 1: Some major bioactive compounds for respiratory disease.

the elastase-treated animals [62]. Several compounds such as epigallocatechin, gallocatechin gallate, berberine, berbamine, coptisine, and dicentrine were reported to involve in the inhibition of viral replication, by inhibiting the viral life cycle in the host and act against the viral-induced respiratory inflammations [160]. The 1,8-cineol isolated from the essential oil of Eucalyptus globulus leaves was studied for its ability to reduce the expression of NF- $\kappa \mathrm{B}$ target gene MUC2 [161]. The 3-methoxy-catalposide had been studied for its ability to inhibit the expression of inducible nitric oxide synthase (iNOS) and cyclooxygenase (COX)-2 in RAW264.7 cells stimulated by LPS. This compound also suppressed the release of nitric oxide (NO) and prostaglandin E2 (PGE2). This compound significantly reduced the activation of inflammatory genes such as interleukins IL- $1 \beta$, IL- 6 , and TNF- $\alpha$ and inhibited the activation of nuclear translocation of NF- $\kappa \mathrm{B}$ and AP-1 [162]. Nepitrin, matte flavonoside G, rutin, etc. were reported to inhibit the influenza virus by damaging the viral membrane, by blocking the viral penetration into the cells, and by sup- pressing neuraminidase in both bacterial and viral infections [163]. Thus, the possible mechanism of action of natural products to reduce the inflammation and diseases in the respiratory system could be by the inhibition of bacteria and viruses and also by the protease-antiprotease balance, NF- $\kappa \mathrm{B}$ activation, oxidative stress, and MAPK pathways. The simple flowchart of the mechanism involved is in Figure 3.

\section{Some Promising Natural Products and Their Pharmacology}

Based on the in vitro and in vivo study, the number of plants based natural products has been studied. Some of them are discussed in detail.

7.1. Piperine. Piperine is a major compound and is a class of alkaloid found in the Piper nigrum fruits. Piperine was reported to be used in pain management, fever, influenza, hypotension, vascular cell modulation, salivation, stimulation 
<smiles>O=c1c2cc(O)c(O)cc2oc2cc(O)c(C3O[C@H](CO)[C@@H](O)[C@H](O)[C@H]3O)c(O)c12</smiles>

Mangiferin

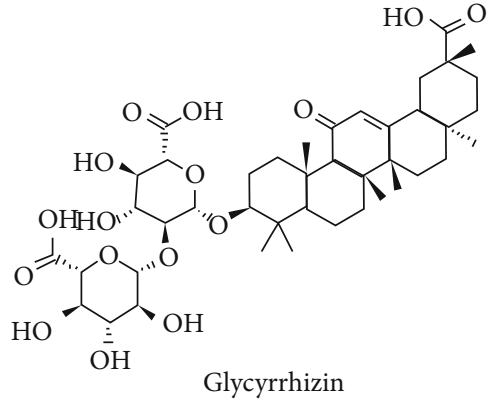

Glycyrrhizin

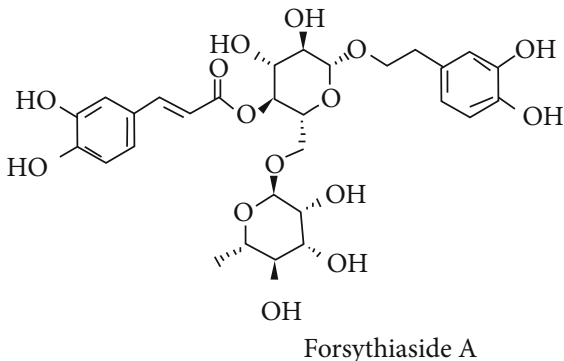<smiles>COc1cc(CCC(C)=O)ccc1O</smiles>

Zingerone Vitexin<smiles>O=C(/C=C/C=C/c1ccc2c(c1)OCO2)N1CCCCC1</smiles>

Piperine<smiles>COc1cc(/C=C/C(=O)CC(=O)/C=C/c2ccc(O)c(OC)c2)ccc1O</smiles>

Curcumin

FIGURE 2: Some promising bioactive compounds for respiratory disease.

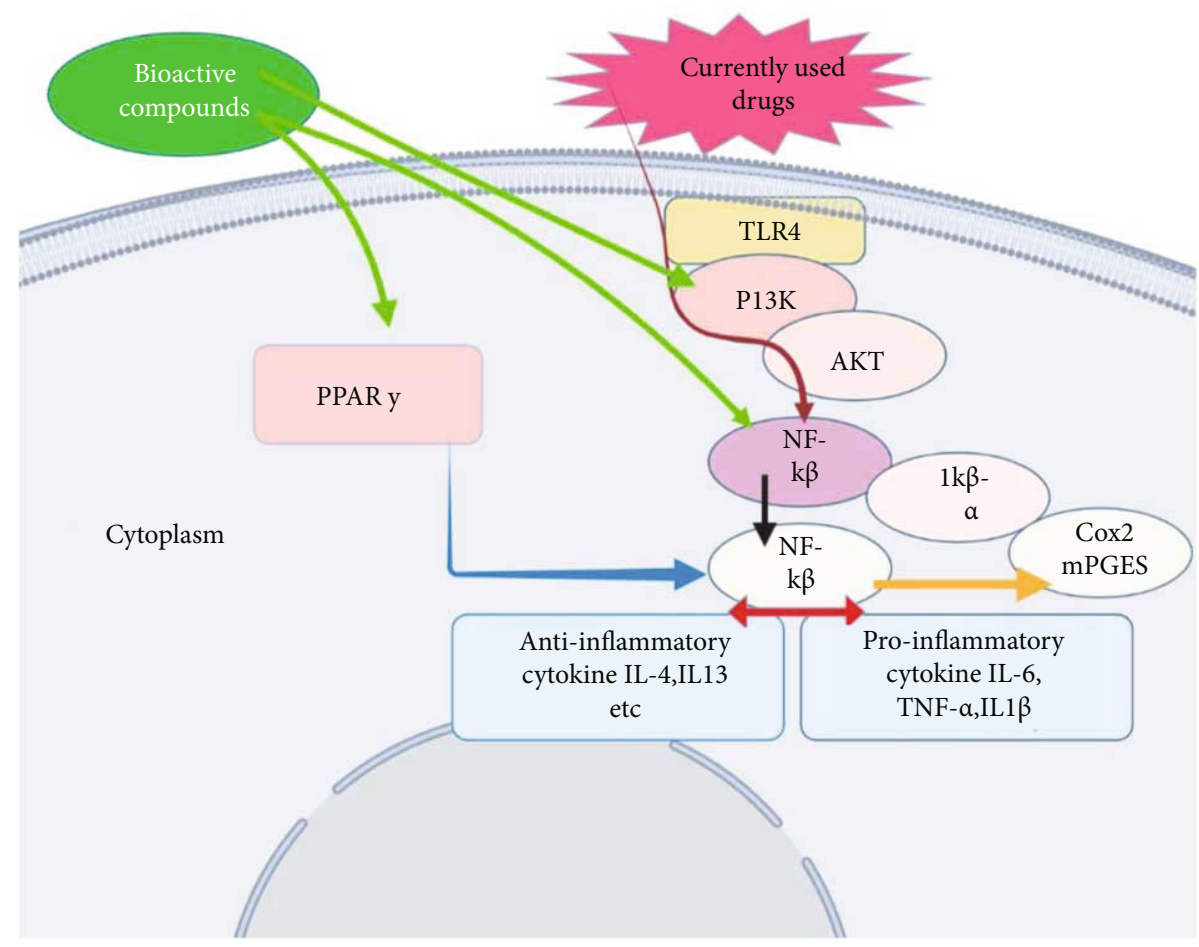

FIGURE 3: Mechanism of action of a natural product in respiratory inflammation.

of appetite, antimicrobial, insecticidal, and chills ([164]). This compound was found to enhance the bioavailability of different drugs. Cosupplementation of piperine with resveratrol was reported to increase its efficacy by enhancing bioavailability [165]. Piperine was reported for its dose-dependent activities in reducing the allergic responses, involving sneezing, nasal rubbing, redness of the nose, etc. [166]. This compound was reported to act as an immunomodulatory and antiallergic effect on ova-albumin-induced rhinitis in the rat, by signifi- cantly ameliorating the sneezing, coughing, and redness induced by sensitizing. The histopathological section of nasal mucosa showed the attenuation of redness and disruption of alveoli and bronchioles [167]. The antitussive activities of plant extracts containing piperine showed the good enhancement of the antitussive effect [168]. The inhibition of tumor growth in the lungs (B16F-10 melanoma cells) was observed after administration of piperine in the mice. The piperine was found to be $100 \%$ cytotoxic to melanoma cells shown by 
histopathology of lungs, resulted in a significant decrease in tumor mass. The alveolar passage and pleura were tumorfree in the piperine-treated mice [169]. The investigation of the efficacy of curcuminoids co-administered with piperine was measured by measuring the serum level of glutathione (GSH) and malondialdehyde (MDA) in sulfur-mustardinduced chronic pulmonary complications and showed the significant increase in GSH and decrease in MDA indicating improvement in COPD status and health-related quality of life (HRQoL) [170]. There are several other pharmacological activities of piperine that can add to the management of several diseases including respiratory inflammation.

7.2. Forsythiaside A. Forsythiaside $\mathrm{A}$ is the pharmacologically active monomer of phenylethanoid glycoside. It is the main active ingredient isolated from the fruit and leaves of Forsythia suspensa. This compound was reported as a potent component that controls inflammation caused by influenza A virus infection by the molecular mechanism through receptor downregulation of the RLRs signaling pathway. It was reported for anti-inflammatory, antioxidant, and antiinfective activities that explained major biological activities [171]. In a recent study, the anti-inflammatory activity in the lungs of mice had been demonstrated well. Forsythiaside was reported to suppress the inflammatory action of cytokines involving (TNF- $\alpha$, IL-6, and IL-1 $\beta$ ) via activating $\mathrm{Nrf} 2$ and inhibiting the NF- $\kappa \mathrm{B}$ signaling pathway in a dose-dependent manner. The number of neutrophils as mediators of inflammation and macrophages was reduced which typically reduced inflammations in the lungs of cigarette and smoke-induced mice [154]. It was reported to act as an immunomodulatory agent which showed an increment in anti-inflammatory cytokines after treatment and restrained the activation of $\mathrm{T}$ cell immune response [172]. Forsythiaside A could be developed as a possible therapeutic candidate against respiratory complications.

7.3. Mangiferin. Mangiferin, a C-glucosyl xanthone, is a natural polyphenolic compound found in Mangifera persiciformis, Mangifera indica, Anemarrhena asphodeloides, Salacia hainanensis, and Mangifera persiciformis, along with other plant species [173]. The major source of mangiferin was reported from bark, fruits, roots, and leaves of the papaya tree, peels and kernels of mango fruits, and the leaves, heartwood, and bark of the mango tree [174]. It was reported to reduce the pathological condition that occurred due to inflammation and was effective in inhibiting inflammatory signaling and treating sepsis with acute lung injury (ALI). Mangiferin suppressed respiratory burst and dramatically reduced the expression of NF- $\kappa \beta$ and proinflammatory cytokines like IL-1, IL-6, and TNF- $\alpha[175,176]$. An in vivo experiment in sepsis-induced mice showed the dosedependent action of mangiferin upregulated the action of HO-1 (heme oxygenase-1) and mediated the inflammation [177]. Mangiferin had a functional effect on the contraction of tracheal rings. It increased NOS3 protein levels and cGMP levels that prevented muscle contraction in the guinea pig. This preclinical experiment suggested mangiferin to be a potent component for treatment in human lung diseases
[178]. It was found to be effective as an immunotherapeutic agent against allergic asthma. The reported results confirmed that mangiferin inhibited PGD2 expression, mediated the level of LTC4, attenuated Th2 cytokines, and displayed a significant role in reducing asthma in a mouse model [179]. The recent studies on mangiferin found the antiallergic properties using a mouse model with allergic rhinitis (AR). The use of mangiferin had a prominent effect in anti-inflammation on nasal tissues. This study further demonstrated the potential of mangiferin in treatment for AR by activating the $\mathrm{Nrf} 2 / \mathrm{H}-\mathrm{O} 1$ signaling pathway and inhibiting NF- $\kappa \mathrm{B}$ [180]. Mangiferin also prevented the formation of the proinflammatory leukotriene LTB4 and decreased the expression of prostaglandin-endoperoxide synthase $2[173,181]$.

7.4. Glycyrrhizin. Glycyrrhizin is a triterpene glycoside made up of one molecule of 18-glycyrrhetinic acid and two glucuronic acid molecules of the composition 18-beta-glycyrrhetinic acid-3-O-beta-D-glucuronopyranosyl-( $1 \rightarrow 2)$-beta-D-glucuronide $[182,183]$. It is a key active ingredient reported from the root of Glycyrrhiza glabra [70]. To examine the effects of glycyrrhizin, a significant anti-inflammatory component found in G. glabra was introduced on mice with OVAinduced asthma; it resulted in the alleviation of asthma diseases by lowering the airway hyperreactivity to methacholine, OVA-induced airway constriction, and lung inflammation including significant eosinophil infiltration [70]. Glycyrrhizin was reported for its antiviral properties against a wide range of RNA and DNA viruses. By observing both in vitro and in vivo experiments, glycyrrhizin had been shown to affect SARS-CoV-2 replication, adsorption, and penetration [184]. Glycyrrhizin dosing could be employed as COVID19 adjuvant or prophylactic therapy [185]. The data showed that applying glycyrrhizin to the nasal and oral cavities could be the first line of defense against SARS-CoV-2 infection in upper respiratory tract cells. Recent clinical studies of anosmia, hyposmia, and dysgeusia in COVID-19 patients reported the nasal and lingual epithelium serves as a gateway for SARS-CoV-2 entrance [186, 187]. This hypothesis is supported by the fact that glycyrrhizin possesses excellent physical features such as amphiphilicity and the capacity to change the characteristics of lipid bilayer membranes.

7.5. Curcumin. Curcumin is a polyphenolic compound that is biologically active and found in the roots of Curcuma longa. It is the active component having wide pharmacological benefits. This compound was reported to suppress inflammation and showed pulmonoprotective effects. It inhibited the NF- $\kappa \mathrm{B}$ and mitogen-activated protein kinase (MAPK) signaling pathways. Treatment with curcumin attenuated the secretion of TNF- $\alpha$, IFN- $\alpha$, and IL- 6 and deals efficiently with the complications [188]. The efficacy of curcumin was reported by various pieces of evidence in lung diseases and was found to be effective and reliable to be used in various respiratory complications like asthma, $\mathrm{COPD}$, lung cancer, and other lung injuries. It was reported to reduce the degree of inflammatory cells and alleviates dysregulation [189]. Curcumin was reported to hold the ability 
to bind with receptors, blocked the entry of the virus into the cells, and interfered with its replication. Lung inflammation due to COVID-19 can be mediated by its uses. Some reports from in silico analysis supported the issue. This potential serves to recommend its implication in therapeutics in COVID-19-induced respiratory complications [190].

7.6. Zingerone. Zingerone is the major component found in the ginger root to about $9.25 \%$. This compound was reported to be closely related to the vanillin from vanilla and eugenol from clove [191]. This compound was reported as a nontoxic compound bearing various pharmacological importance. This compound was extensively studied for its effect on lung injuries. It significantly lessened the pulmonary edema, attenuated the amount of TNF- $\alpha$ and IL- $\beta$ in BALF, and inhibited proinflammatory cytokine release in acute lung injury in mice [151]. The hepatoprotective effect of zingerone had been studied in the LPS-induced hepatic injury in mice in terms of liver histology, liver function marker, and several other inflammatory markers such as TNF- $\alpha$, TLR4, and iNOS parameters. The zingerone-treated group showed significant improvement in liver histology, decreased endotoxin level, improved liver function markers, and downregulation of mRNA expression of TNF- $\alpha$, TLR4, and iNOS indicating better anti-inflammatory activities.

7.7. Vitexin. Vitexin (apigenin-8-C- $\beta$-D-glucopyranoside) is a flavone glycoside of apigenin found in food and medicinal plants such as the hawthorn leaf [192], bamboo [193], buckwheat [194], Passiflora [195], and Echinodorus [196]. Vitexin was reported as a significant polyphenol present in foods such as mung beans [197], which are frequently utilized in traditional Chinese medicine [192]. In the gastrointestinal tract, vitexin is poorly absorbed. It is rapidly eliminated from the bloodstream, primarily eliminated in the urine and bile [198]. This compound is reported to have very poor absolute oral bioavailability and is quickly and broadly disseminated throughout the body. The buildup of reactive oxygen species (ROS) exacerbated inflammatory reactions by boosting the release of proinflammatory cytokines and inflammatory cell infiltration [199]. When compared to vehicle-treated mice, vitexin administration reduced LPS-induced ROS levels by $44 \%$. Vitexin therapy reduced neutrophils and the production of proinflammatory cytokines. This compound reduced pulmonary edema and protein concentration in the alveoli. The activity of Nrf2 and HO-1 was significantly increased after treatment with vitexin. Vitexin also boosted the activity of its target gene, heme oxygenase (HO)-1, via activating nuclear factor erythroid-2-related factor 2 (Nrf2) [103].

\section{Conclusion and Future Perspective}

In this review, the drawbacks and limitations of currently adopted treatment procedures and available drugs have been highlighted. This study also reported the several plant species that are being used in the treatment of respiratory complications in the traditional medicinal system based on traditional knowledge and indigenous knowledge. The reported bioactive compounds and their mechanism of action have been critically analyzed for possible therapeutic compounds. Some of the plant products are promising against respiratory diseases and can be the best source of alternative medicine. Although, some clinical shreds of evidence have been reported for some of the compounds, there needs to be an extensive study on the toxicological aspect and interaction with other therapeutics. The detail studies on the formulations, forms of doses, evaluation of pharmacokinetic parameter, and safety are necessary. The future study should focus on the identification and isolation of more effective compounds, their mechanism of action, and formulations. This study can facilitate the newly discovered compounds to enter a clinical trial. Therefore, it is concluded that further research on the traditionally used plants and plant-derived products could lead to the discovery of a new kind of therapeutic drug of high potential and interest.

\section{Conflicts of Interest}

The authors declare no potential conflict of interest.

\section{Authors' Contributions}

D.T. conceived the idea and prepared the first draft of the manuscript. D.B. and K.P. searched the literature and added it to the manuscript. D.T. supervised the project and revised the manuscript. All authors read and approved the final version of the manuscript before submission.

\section{References}

[1] H. P. Kim, H. Lim, and Y. S. Kwon, “Therapeutic potential of medicinal plants and their constituents on lung inflammatory disorders," Biomolecules \& Therapeutics, vol. 25, no. 2, pp. 91-104, 2017.

[2] W. Guan, Y. Peng, X. X. Zi et al., "Motile ciliary disorders in chronic airway inflammatory diseases: critical target for interventions," Current Allergy and Asthma Reports, vol. 18, no. 9 , p. 48, 2018.

[3] H. Shen, S. Ying, Z. Bao, J. Xiong, W. Li, and Z. Chen, "Genomic instability in chronic airway inflammatory diseases," Biomedical Journal, vol. 38, no. 2, pp. 117-124, 2015.

[4] P. V. Dasaraju and C. Liu, "Infections of the respiratory system," in Medical Microbiology, S. Baron, Ed., University of Texas Medical Branch at Galveston, Galveston (TX), 4th edition, 1996.

[5] L. D. C. Costa, P. S. Costa, and P. A. M. Camargos, "Exacerbaçao da asma e infecçao das vias aereas: o virus e o vilao?," Jornal de Pediatria, vol. 90, no. 6, pp. 542-555, 2014.

[6] T. J. Braciale, J. Sun, and T. S. Kim, "Regulating the adaptive immune response to respiratory virus infection," Nature Reviews. Immunology, vol. 12, no. 4, pp. 295-305, 2012.

[7] W. W. Busse, R. F. Lemanske Jr., and J. E. Gern, "Role of viral respiratory infections in asthma and asthma exacerbations," The Lancet, vol. 376, no. 9743, pp. 826-834, 2010.

[8] C. J. Britto, V. Brady, S. Lee, and C. S. dela Cruz, "Respiratory viral infections in chronic lung diseases," Clinics in Chest Medicine, vol. 38, no. 1, pp. 87-96, 2017. 
[9] D. Linden, H. Guo-Parke, P. V. Coyle et al., "Respiratory viral infection: a potential "missing link" in the pathogenesis of COPD," European Respiratory Review, vol. 28, no. 151, p. $180063,2019$.

[10] A. Singanayagam, N. Glanville, J. L. Girkin et al., "Corticosteroid suppression of antiviral immunity increases bacterial loads and mucus production in COPD exacerbations," Nature Communications, vol. 9, no. 1, pp. 2229-2229, 2018.

[11] J. Wang, S. Watanabe, S. Matsukura, and H. Suzaki, "Doublestranded RNA poly(I:C) enhances matrix metalloproteinase mRNA expression in human nasal polyp epithelial cells," Acta Oto-Laryngologica, vol. 129, Supplement 562, pp. 105109, 2009.

[12] C. Viniol and C. F. Vogelmeier, "Exacerbations of COPD," European Respiratory Review, vol. 27, no. 147, p. 170103, 2018.

[13] C. J. Corrigan and A. B. Kay, "The roles of inflammatory cells in the pathogenesis of asthma and of chronic obstructive pulmonary disease," The American Review of Respiratory Disease, vol. 143, 5 Part 1, pp. 1165-1168, 1991.

[14] A. Rossi and G. Polese, "Indacaterol: a comprehensive review," International Journal of Chronic Obstructive Pulmonary Disease, vol. 8, pp. 353-363, 2013.

[15] T. Bouyssou, P. Casarosa, E. Naline et al., "Pharmacological characterization of olodaterol, a novel inhaled $\beta 2$-Adrenoceptor agonist exerting a 24-hour-long duration of action in preclinical models," The Journal of Pharmacology and Experimental Therapeutics, vol. 334, no. 1, pp. 53-62, 2010.

[16] R. J. Slack, V. J. Barrett, V. S. Morrison et al., "In vitro pharmacological characterization of vilanterol, a novel LongActing $\beta 2$-Adrenoceptor agonist with 24-hour duration of action," The Journal of Pharmacology and Experimental Therapeutics, vol. 344, no. 1, pp. 218-230, 2013.

[17] M. Q. Abideen, A. Adnan, K. Z. Gul, R. Muhammad, and M. A. Bilquees, "Traditional ethno-botanical uses of medicinal plants from coastal areas of Pakistan," Journal of Coastal Life Medicine, 2014.

[18] N. Rajakumar and M. B. Shivanna, "Ethno-medicinal application of plants in the eastern region of Shimoga District, Karnataka, India," Journal of Ethnopharmacology, vol. 126, no. 1, pp. 64-73, 2009.

[19] P. J. Barnes, "Triple inhalers for obstructive airways disease: will they be useful?," Expert Review of Respiratory Medicine, vol. 5, no. 3, pp. 297-300, 2011.

[20] S. Singh and N. Singh, "Current trends of management of respiratory diseases by pulmonologists: results of National Conference of Pulmonary Disease - 2015 survey," Lung India, vol. 34, no. 1, pp. 13-18, 2017.

[21] M. Caminati, M. S. Magnoni, A. Rizzi et al., "Asthma management among different specialists: results from a national Italian survey," European Annals of Allergy and Clinical Immunology, vol. 46, no. 2, pp. 74-82, 2014.

[22] P. G. Woodruff, R. G. Barr, E. Bleecker et al., "Clinical significance of symptoms in smokers with preserved pulmonary function," The New England Journal of Medicine, vol. 374, no. 19, pp. 1811-1821, 2016.

[23] M. Cazzola, C. P. Page, L. Calzetta, and M. G. Matera, "Pharmacology and therapeutics of bronchodilators," Pharmacological Reviews, vol. 64, no. 3, pp. 450-504, 2012.

[24] D. M. Williams, "Clinical pharmacology of corticosteroids," Respiratory Care, vol. 63, no. 6, pp. 655-670, 2018.
[25] S. Bindu, S. Mazumder, and U. Bandyopadhyay, "Non-steroidal anti-inflammatory drugs (NSAIDs) and organ damage: a current perspective," Biochemical Pharmacology, vol. 180, p. 114147, 2020.

[26] I. Ghlichloo and V. Gerriets, "Nonsteroidal anti-inflammatory drugs (NSAIDs)," in StatPearls, StatPearls Publishing, Treasure Island (FL), 2021, http://www.ncbi.nlm.nih.gov/books/ NBK547742/.

[27] M. G. Matera, C. P. Page, and M. Cazzola, "Novel bronchodilators for the treatment of chronic obstructive pulmonary disease," Trends in Pharmacological Sciences, vol. 32, no. 8, pp. 495-506, 2011.

[28] C. Page and M. Cazzola, "Bifunctional drugs for the treatment of asthma and chronic obstructive pulmonary disease," The European Respiratory Journal, vol. 44, no. 2, pp. 475-482, 2014.

[29] K. Lechowicz, S. Drożdżal, F. Machaj et al., "COVID-19: the potential treatment of pulmonary fibrosis associated with SARS-CoV-2 infection," Journal of Clinical Medicine, vol. 9, no. 6, p. 1917, 2020.

[30] F. Bani-Sadr, M. Hentzien, M. Pascard et al., "Corticosteroid therapy for patients with COVID-19 pneumonia: a beforeafter study," International Journal of Antimicrobial Agents, vol. 56, no. 2, p. 106077, 2020.

[31] D. Pasero, S. Sanna, C. Liperi et al., "A challenging complication following SARS-CoV-2 infection: a case of pulmonary mucormycosis," Infection, 2020.

[32] S. H. Chotirmall, M. al-Alawi, B. Mirkovic et al., "Aspergillusassociated airway disease, inflammation, and the innate immune response," BioMed Research International, vol. 2013, Article ID 723129, 14 pages, 2013.

[33] Fulcrum Therapeutics, "A phase 3, randomized, double-blind, placebo-controlled study of the safety and efficacy of losmapimod in adult subjects with COVID-19 (LOSVID study) clinicaltrials.gov, Clinical trial registration NCT04511819," 2021, June 2021, https://clinicaltrials.gov/ct2/show/NCT04511819.

[34] H. Watz, H. Barnacle, B. F. Hartley, and R. Chan, "Efficacy and safety of the p38 MAPK inhibitor losmapimod for patients with chronic obstructive pulmonary disease: a randomised, double-blind, placebo- controlled trial," The Lancet Respiratory Medicine, vol. 2, no. 1, pp. 63-72, 2014.

[35] J. M. Grimes and K. V. Grimes, "p38 MAPK inhibition: a promising therapeutic approach for COVID-19," Journal of Molecular and Cellular Cardiology, vol. 144, pp. 63-65, 2020.

[36] L. D. Tan, D. Gódor, J. Bratt, N. J. Kenyon, and S. Louie, "Benralizumab: a unique IL-5 inhibitor for severe asthma," Journal of Asthma and Allergy, vol. 9, pp. 71-81, 2016.

[37] R. M. Nowak, J. M. Parker, R. A. Silverman et al., "A randomized trial of benralizumab, an antiinterleukin 5 receptor $\alpha$ monoclonal antibody, after acute asthma," The American Journal of Emergency Medicine, vol. 33, no. 1, pp. 14-20, 2015.

[38] A. Varricchio, I. La Mantia, F. P. Brunese, and G. Ciprandi, "Inflammation, infection, and allergy of upper airways: new insights from national and real-world studies," Italian Journal of Pediatrics, vol. 46, no. 1, p. 18, 2020.

[39] T.-R. Min, H. J. Park, M. N. Park, B. Kim, and S. H. Park, "The root bark of Morus alba L. suppressed the migration of human non-small-cell lung cancer cells through inhibition of epithelial ${ }^{-}$mesenchymal transition mediated by STAT3 
and Src," International Journal of Molecular Sciences, vol. 20, no. 9, p. 2244, 2019.

[40] M. S. Amjad, M. F. Qaeem, I. Ahmad et al., "Descriptive study of plant resources in the context of the ethnomedicinal relevance of indigenous flora: a case study from Toli Peer National Park, Azad Jammu and Kashmir, Pakistan," PLoS One, vol. 12, no. 2, article e0171896, 2017.

[41] A. G. Singh, A. Kumar, and D. Tewari, "An ethnobotanical survey of medicinal plants used in Terai forest of western Nepal," Journal of Ethnobiology and Ethnomedicine, vol. 8, no. 1, p. 19, 2012.

[42] I. O. Lawal, I. I. Olufade, B. O. Rafiu, and A. O. Aremu, "Ethnobotanical survey of plants used for treating cough associated with respiratory conditions in Ede South local government area of Osun State, Nigeria," Plants, vol. 9, no. 5, p. 647, 2020.

[43] Y. M. M. Kyaw, Y. Bi, T. N. Oo, and X. Yang, "Traditional medicinal plants used by the Mon people in Myanmar," Journal of Ethnopharmacology, vol. 265, p. 113253, 2021.

[44] H. Gumisiriza, G. Birungi, E. A. Olet, and C. D. Sesaazi, "Medicinal plant species used by local communities around Queen Elizabeth National Park, Maramagambo Central Forest Reserve and Ihimbo Central Forest Reserve, South western Uganda," Journal of Ethnopharmacology, vol. 239, p. 111926, 2019.

[45] A. Mahmood, A. Mahmood, R. N. Malik, and Z. K. Shinwari, "Indigenous knowledge of medicinal plants from Gujranwala district, Pakistan," Journal of Ethnopharmacology, vol. 148, no. 2, pp. 714-723, 2013.

[46] Alamgeer, W. Younis, H. Asif et al., "Traditional medicinal plants used for respiratory disorders in Pakistan: a review of the ethno-medicinal and pharmacological evidence," Chinese Medicine, vol. 13, no. 1, p. 48, 2018.

[47] N. Shrestha, S. Shrestha, L. Koju, K. K. Shrestha, and Z. Wang, "Medicinal plant diversity and traditional healing practices in eastern Nepal," Journal of Ethnopharmacology, vol. 192, pp. 292-301, 2016.

[48] M. B. Rokaya, Z. Münzbergová, and B. Timsina, "Ethnobotanical study of medicinal plants from the Humla district of western Nepal," Journal of Ethnopharmacology, vol. 130, no. 3, pp. 485-504, 2010.

[49] K. Ahmad and S. Habib, "Indigenous knowledge of some medicinal plants of Himalaya Region, Dawarian Village, Neelum Valley, Azad Jammu and Kashmir, Pakistan," Universal Journal of Plant Science, vol. 2, no. 2, pp. 40-47, 2014.

[50] N. Ahmed, A. Mahmood, A. Mahmood et al., "Relative importance of indigenous medicinal plants from Layyah district, Punjab Province, Pakistan," Journal of Ethnopharmacology, vol. 155, no. 1, pp. 509-523, 2014.

[51] N. Ahmed, A. Mahmood, A. Mahmood, Z. Sadeghi, and M. Farman, "Ethnopharmacological importance of medicinal flora from the district of Vehari, Punjab Province, Pakistan," Journal of Ethnopharmacology, vol. 168, pp. 66-78, 2015.

[52] B. Sisay, E. Debebe, A. Meresa et al., "Phytochemistry and method preparation of some medicinal plants used to treat asthma-review," Journal of Analytical \& Pharmaceutical Research, vol. 9, no. 3, pp. 107-115, 2020.

[53] N. Shrestha, D. Prasai, K. K. Shrestha, S. Shrestha, and X. C. Zhang, "Ethnomedicinal practices in the highlands of central Nepal: a case study of Syaphru and Langtang Village in
Rasuwa District," Journal of Ethnopharmacology, vol. 155, no. 2, pp. 1204-1213, 2014.

[54] D. Khadka, M. K. Dhamala, F. Li et al., "The use of medicinal plants to prevent COVID-19 in Nepal," Journal of Ethnobiology and Ethnomedicine, vol. 17, no. 1, p. 26, 2021.

[55] S. Begum, N. AbdEIslam, M. Adnan, A. Tariq, A. Yasmin, and R. Hameed, "Ethnomedicines of highly utilized plants in the temperate Himalayan region," African Journal of Traditional, Complementary and Alternative Medicines, vol. 11, no. 3, pp. 132-142, 2014.

[56] M. Dutta, M. Nezam, S. Chowdhury et al., "Appraisals of the Bangladeshi medicinal plant Calotropis gigantea used by folk medicine practitioners in the management of COVID-19: a biochemical and computational approach," Frontiers in Molecular Biosciences, vol. 8, p. 625391, 2021.

[57] A. Ullah, A. Rashid, and S. N. Parveen, Medicinal plants used in the isolated region of Bumburet, Kalash Valley, District Chitral, Pakistan, p. 15, 2014.

[58] S. Shil, M. Dutta Choudhury, and S. Das, "Indigenous knowledge of medicinal plants used by the Reang tribe of Tripura State of India," Journal of Ethnopharmacology, vol. 152, no. 1, pp. 135-141, 2014.

[59] A. Bano, M. Ahmad, M. Zafar, S. Sultana, S. Rashid, and M. A. Khan, "Ethnomedicinal knowledge of the most commonly used plants from Deosai Plateau, Western Himalayas, Gilgit Baltistan, Pakistan," Journal of Ethnopharmacology, vol. 155, no. 2, pp. 1046-1052, 2014.

[60] M. Ishtiaq, A. Mahmood, and M. Maqbool, "Indigenous knowledge of medicinal plants from Sudhanoti District (AJK), Pakistan," Journal of Ethnopharmacology, vol. 168, pp. 201-207, 2015.

[61] H. J. Lim, H. G. Jin, E. R. Woo, S. K. Lee, and H. P. Kim, "The root barks of Morus alba and the flavonoid constituents inhibit airway inflammation," Journal of Ethnopharmacology, vol. 149, no. 1, pp. 169-175, 2013.

[62] L. Taguchi, N. M. Pinheiro, C. R. Olivo et al., "A flavanone from Baccharis retusa (Asteraceae) prevents elastaseinduced emphysema in mice by regulating NF- $\kappa \mathrm{B}$, oxidative stress and metalloproteinases," Respiratory Research, vol. 16, no. 1, p. 79, 2015.

[63] S. Bansal and S. Chhibber, "Curcumin alone and in combination with augmentin protects against pulmonaryinflammation and acute lung injury generated during Klebsiella pneumoniae B5055-induced lung infection in BALB/c mice," Journal of Medical Microbiology, vol. 59, Part 4, pp. 429-437, 2010.

[64] J. Sharifi-Rad, Y. E. Rayess, A. A. Rizk et al., "Turmeric and its major compound curcumin on health: bioactive effects and safety profiles for food, pharmaceutical, biotechnological and medicinal applications," Frontiers in Pharmacology, vol. 11, article 01021, 2020.

[65] M. Lee, S. Kim, O. K. Kwon, S. R. Oh, H. K. Lee, and K. Ahn, "Anti-inflammatory and anti-asthmatic effects of resveratrol, a polyphenolic stilbene, in a mouse model of allergic asthma," International Immunopharmacology, vol. 9, no. 4, pp. 418424, 2009.

[66] J. Lee, Y. C. Li, H. Y. Chen et al., "Protective effects of luteolin against lipopolysaccharide-induced acute lung injury involves inhibition of MEK/ERK and PI3K/Akt pathways in neutrophils," Acta Pharmacologica Sinica, vol. 31, no. 7, pp. 831-838, 2010. 
[67] S.-H. Kim and Y. C. Lee, "Piperine inhibits eosinophil infiltration and airway hyperresponsiveness by suppressing $\mathrm{T}$ cell activity and Th2 cytokine production in the ovalbumininduced asthma model," The Journal of Pharmacy and Pharmacology, vol. 61, no. 3, pp. 353-359, 2009.

[68] H. J. Lim, J. H. Lee, J. S. Choi, S. K. Lee, Y. S. Kim, and H. P. Kim, "Inhibition of airway inflammation by the roots of Angelica decursiva and its constituent, columbianadin," Journal of Ethnopharmacology, vol. 155, no. 2, pp. 1353-1361, 2014.

[69] K. Gulati, N. Rai, S. Chaudhary, and A. Ray, "Nutraceuticals in respiratory disorders," in Nutraceuticals, pp. 75-86, 2016.

[70] A. Ram, U. Mabalirajan, M. Das et al., "Glycyrrhizin alleviates experimental allergic asthma in mice," International Immunopharmacology, vol. 6, no. 9, pp. 1468-1477, 2006.

[71] D. Timalsina, H. P. Devkota, D. Bhusal, and K. R. Sharma, "Catunaregam spinosa (Thunb.) Tirveng: a review of traditional uses, phytochemistry, pharmacological activities, and toxicological aspects," Evidence-based Complementary and Alternative Medicine, vol. 2021, Article ID 3257732, 10 pages, 2021.

[72] R. Marahatha, K. Gyawali, K. Sharma et al., "Pharmacologic activities of phytosteroids in inflammatory diseases: mechanism of action and therapeutic potentials," Phytotherapy Research, vol. 35, no. 9, pp. 5103-5124, 2021.

[73] S. G. Peters, J. C. McDougall, W. W. Douglas, D. T. Coles, and R. A. DeRemee, "Colchicine in the treatment of pulmonary fibrosis," Chest, vol. 103, no. 1, pp. 101-104, 1993.

[74] C. Bezerra-Santos, A. Vieira-de-Abreu, G. C. Vieira et al., "Effectiveness of Cissampelos sympodialis and its isolated alkaloid warifteine in airway hyperreactivity and lung remodeling in a mouse model of asthma," International Immunopharmacology, vol. 13, no. 2, pp. 148-155, 2012.

[75] D. Wang, Q. du, H. Li, and S. Wang, "The isosteroid alkaloid imperialine from bulbs of Fritillaria cirrhosa mitigates pulmonary functional and structural impairment and suppresses inflammatory response in a COPD-like rat model," Mediators of Inflammation, vol. 2016, Article ID 4192483, 17 pages, 2016.

[76] H. Huang, G. Hu, C. Wang, H. Xu, X. Chen, and A. Qian, "Cepharanthine, an alkaloid from Stephania cepharantha Hayata, inhibits the inflammatory response in the RAW264.7 cell and mouse models," Inflammation, vol. 37, no. 1, pp. 235-246, 2014.

[77] H. I. Umar, T. P. Saliu, S. S. Josiah, A. Ajayi, and J. B. Danjuma, "In silico studies of bioactive compounds from selected African plants with inhibitory activity against nitric oxide synthase and arginase implicated in asthma," Egyptian Journal of Medical Human Genetics, vol. 22, no. 1, p. 60, 2021.

[78] W. Liu, Y. Wang, D. D. He et al., "Antitussive, expectorant, and bronchodilating effects of quinazoline alkaloids $( \pm$ )-vasicine, deoxyvasicine, and $( \pm)$-vasicinone from aerial parts of Peganum harmala L," Phytomedicine : international journal of phytotherapy and phytopharmacology., vol. 22, no. 12, pp. 1088-1095, 2015.

[79] A. Ribeiro, V. I. Almeida, C. Costola-de-Souza et al., "Cannabidiol improves lung function and inflammation in mice submitted to LPS-induced acute lung injury," Immunopharmacology and Immunotoxicology, vol. 37, no. 1, pp. 35-41, 2015.

[80] A. Ribeiro, V. Ferraz-de-Paula, M. L. Pinheiro et al., "Cannabidiol, a non-psychotropic plant-derived cannabinoid, decreases inflammation in a murine model of acute lung injury: Role for the adenosine $\mathrm{A}_{2 \mathrm{~A}}$ receptor," European Journal of Pharmacology, vol. 678, no. 1-3, pp. 78-85, 2012.

[81] L. W. Soromou, X. Chu, L. Jiang et al., "In vitro and in vivo protection provided by pinocembrin against lipopolysaccharideinduced inflammatory responses," International Immunopharmacology, vol. 14, no. 1, pp. 66-74, 2012.

[82] Z. Chen, P. Chen, H. Wu et al., "Evaluation of naringenin as a promising treatment option for COPD based on literature review and network pharmacology," Biomolecules, vol. 10, no. 12, p. 1644, 2020.

[83] M. Zhao, C. Li, F. Shen, M. Wang, N. Jia, and C. Wang, "Naringenin ameliorates LPS-induced acute lung injury through its anti-oxidative and anti-inflammatory activity and by inhibition of the PI3K/AKT pathway," Experimental and Therapeutic Medicine, vol. 14, no. 3, pp. 2228-2234, 2017.

[84] C. Zhang, W. Zeng, Y. Yao et al., "Naringenin ameliorates radiation-induced lung injury by lowering IL-1 $\beta$ Level," The Journal of Pharmacology and Experimental Therapeutics, vol. 366, no. 2, pp. 341-348, 2018.

[85] M. Huo, N. Chen, G. Chi et al., "Traditional medicine alpinetin inhibits the inflammatory response in Raw 264.7 cells and mouse models," International Immunopharmacology, vol. 12, no. 1, pp. 241-248, 2012.

[86] G. F. Zhu, H. J. Guo, Y. Huang, C. T. Wu, and X. F. Zhang, "Eriodictyol, a plant flavonoid, attenuates LPS-induced acute lung injury through its antioxidative and anti-inflammatory activity," Experimental and Therapeutic Medicine, vol. 10, no. 6, pp. 2259-2266, 2015.

[87] Y.-C. Xie, X. W. Dong, X. M. Wu, X. F. Yan, and Q. M. Xie, "Inhibitory effects of flavonoids extracted from licorice on lipopolysaccharide-induced acute pulmonary inflammation in mice," International Immunopharmacology, vol. 9, no. 2, pp. 194-200, 2009.

[88] D. Yu, X. Liu, G. Zhang, Z. Ming, and T. Wang, "Isoliquiritigenin inhibits cigarette smoke-induced COPD by attenuating inflammation and oxidative stress via the regulation of the Nrf2 and NF- $\kappa$ B signaling pathways," Frontiers in Pharmacology, vol. 9, 2018.

[89] J. Liu, Y. Wei, Q. Luo et al., "Baicalin attenuates inflammation in mice with OVA-induced asthma by inhibiting NF$\kappa \mathrm{B}$ and suppressing CCR7/CCL19/CCL21," International Journal of Molecular Medicine, vol. 38, no. 5, pp. 15411548, 2016.

[90] Z. Lixuan, D. Jingcheng, Y. Wenqin, H. Jianhua, L. Baojun, and F. Xiaotao, "Baicalin attenuates inflammation by inhibiting NF- $\kappa$ B activation in cigarette smoke induced inflammatory models," Pulmonary Pharmacology \& Therapeutics, vol. 23, no. 5, pp. 411-419, 2010.

[91] H.-J. Zhi, H. Y. Zhu, Y. Y. Zhang, Y. Lu, H. Li, and D. F. Chen, "In vivo effect of quantified flavonoids-enriched extract of Scutellaria baicalensis root on acute lung injury induced by influenza A virus," Phytomedicine Int. J. Phytother. Phytopharm., vol. 57, pp. 105-116, 2019.

[92] J. H. Lee, H. J. Ko, E. R. Woo et al., "Moracin M inhibits airway inflammation by interrupting the JNK/c-Jun and NF- $\kappa \mathrm{B}$ pathways in vitro and in vivo," European Journal of Pharmacology, vol. 783, pp. 64-72, 2016.

[93] G. O. de Melo, M. F. Muzitano, A. Legora-Machado et al., "Cglycosylflavones from the aerial parts of Eleusine indica inhibit LPS-induced mouse lung inflammation," Planta Medica, vol. 71, no. 4, pp. 362-363, 2005. 
[94] X.-X. Zhang, Q. F. Wu, Y. L. Yan, and F. L. Zhang, "Inhibitory effects and related molecular mechanisms of total flavonoids in Mosla chinensis Maxim against H1N1 influenza virus," Inflammation Research, vol. 67, no. 2, pp. 179-189, 2018.

[95] J. Chen, J. B. Wang, C. H. Yu, L. Q. Chen, P. Xu, and W. Y. $\mathrm{Yu}$, "Total flavonoids of Mosla scabra leaves attenuates lipopolysaccharide- induced acute lung injury via downregulation of inflammatory signaling in mice," Journal of Ethnopharmacology, vol. 148, no. 3, pp. 835-841, 2013.

[96] L.-J. Feng, C. H. Yu, K. J. Ying, J. Hua, and X. Y. Dai, "Hypolipidemic and antioxidant effects of total flavonoids of Perilla Frutescens leaves in hyperlipidemia rats induced by high-fat diet," Food Research International, vol. 44, no. 1, pp. 404409, 2011.

[97] X. Zheng, L. Zhang, W. W. Wang, Y. Y. Wu, Q. B. Zhang, and W. S. Feng, "Anti-diabetic activity and potential mechanism of total flavonoids of Selaginella tamariscina (Beauv.) Spring in rats induced by high fat diet and low dose STZ," Journal of Ethnopharmacology, vol. 137, no. 1, pp. 662-668, 2011.

[98] J. Wang, Y. T. Liu, L. Xiao, L. Zhu, Q. Wang, and T. Yan, "Anti-inflammatory effects of apigenin in lipopolysaccharideinduced inflammatory in acute lung injury by suppressing COX-2 and NF-kB pathway," Inflammation, vol. 37, no. 6 , pp. 2085-2090, 2014.

[99] T. Xiao, M. Cui, C. Zheng et al., "Myricetin inhibits SARSCoV-2 viral replication by targeting $\mathrm{M}^{\text {pro }}$ and ameliorates pulmonary inflammation," Frontiers in Pharmacology, vol. 12, 2021.

[100] W. Wang, Q. Yao, F. Teng, J. Cui, J. Dong, and Y. Wei, "Active ingredients from Chinese medicine plants as therapeutic strategies for asthma: overview and challenges," Biomedicine \& Pharmacotherapy, vol. 137, p. 111383, 2021.

[101] C. Mouffouk, S. Mouffouk, S. Mouffouk, L. Hambaba, and H. Haba, "Flavonols as potential antiviral drugs targeting SARS-CoV-2 proteases ( $3 \mathrm{CL}^{\text {pro }}$ and $\left.\mathrm{PL}^{\text {pro }}\right)$, spike protein, RNA-dependent RNA polymerase (RdRp) and angiotensinconverting enzyme II receptor (ACE2)," European Journal of Pharmacology, vol. 891, p. 173759, 2021.

[102] M.-Y. Wu, S. K. Hung, and S. L. Fu, "Immunosuppressive effects of fisetin in ovalbumin-induced asthma through inhibition of NF- $\kappa \mathrm{B}$ activity," Journal of Agricultural and Food Chemistry, vol. 59, no. 19, pp. 10496-10504, 2011.

[103] Y. Lu, T. Yu, J. Liu, and L. Gu, "Vitexin attenuates lipopolysaccharide-induced acute lung injury by controlling the Nrf2 pathway," PLoS One, vol. 13, no. 4, article e0196405, 2018.

[104] L.-J. Ling, Y. Lu, Y. Y. Zhang et al., "Flavonoids from Houttuynia cordata attenuate H1N1-induced acute lung injury in mice via inhibition of influenza virus and Toll-like receptor signalling," Phytomedicine, vol. 67, p. 153150, 2020.

[105] J. H. Lee, J. Ahn, J. W. Kim, S. G. Lee, and H. P. Kim, "Flavonoids from the aerial parts of Houttuynia cordata attenuate lung inflammation in mice," Archives of Pharmacal Research, vol. 38, no. 7, pp. 1304-1311, 2015.

[106] S. Noh, K. S. Ahn, S. R. Oh, K. H. Kim, and M. Joo, "Neutrophilic lung inflammation suppressed by picroside II Is associated with TGF- $\beta$ signaling," Evidence-Based Complementary and Alternative Medicine, vol. 2015, Article ID 897272, 11 pages, 2015.

[107] F. Yunhe, L. Bo, F. Xiaosheng et al., "The effect of magnolol on the toll-like receptor 4/nuclear factor kappa B signaling pathway in lipopolysaccharide-induced acute lung injury in mice," European Journal of Pharmacology, vol. 689, no. 1-3, pp. 255-261, 2012.

[108] W. Zhong, Y. C. Wu, X. X. Xie et al., "Phillyrin attenuates LPS-induced pulmonary inflammation via suppression of MAPK and NF- $\kappa$ B activation in acute lung injury mice," Fitoterapia, vol. 90, pp. 132-139, 2013.

[109] E. Zhou, Y. Li, Z. Wei et al., "Schisantherin A protects lipopolysaccharide-induced acute respiratory distress syndrome in mice through inhibiting NF- $\kappa$ B and MAPKs signaling pathways," International Immunopharmacology, vol. 22, no. 1, pp. 133-140, 2014.

[110] Y. Chen, Y. Kong, Q. Wang et al., "Schisandrin B attenuates airway inflammation by regulating the NF- $\kappa \mathrm{B} / \mathrm{Nrf} 2$ signaling pathway in mouse models of asthma," Journal of Immunology Research, vol. 2021, Article ID 8029963, 13 pages, 2021.

[111] Y.-Y. Xu, Y. Y. Zhang, Y. Y. Ou et al., "Houttuynia cordata Thunb. polysaccharides ameliorates lipopolysaccharideinduced acute lung injury in mice," Journal of Ethnopharmacology, vol. 173, pp. 81-90, 2015.

[112] H. Zhu, X. Lu, L. Ling et al., "Houttuynia cordata polysaccharides ameliorate pneumonia severity and intestinal injury in mice with influenza virus infection," Journal of Ethnopharmacology, vol. 218, pp. 90-99, 2018.

[113] L. Amaral-Machado, W. N. Oliveira, S. S. Moreira-Oliveira et al., "Use of natural products in asthma treatment," Evidence-based Complementary and Alternative Medicine, vol. 2020, Article ID 1021258, 35 pages, 2020.

[114] C. Li, Y. Huang, X. Yao et al., "Lugrandoside attenuates LPSinduced acute respiratory distress syndrome by antiinflammation and anti-apoptosis in mice," American Journal of Translational Research, vol. 8, no. 12, pp. 5557-5568, 2016.

[115] J. H. Lee, D. S. Min, C. W. Lee, K. H. Song, Y. S. Kim, and H. P. Kim, "Ginsenosides from Korean Red Ginseng ameliorate lung inflammatory responses: inhibition of the MAPKs/NF- $\kappa \mathrm{B} / \mathrm{c}-\mathrm{Fos}$ pathways," Journal of Ginseng Research, vol. 42, no. 4, pp. 476-484, 2018.

[116] J. H. Lee, H. J. Lim, C. W. Lee et al., "Methyl protodioscin from the roots of Asparagus cochinchinensis attenuates airway inflammation by inhibiting cytokine production," Evidence-Based Complementary and Alternative Medicine, vol. 2015, Article ID 640846, 12 pages, 2015.

[117] D. Shi, M. Zheng, Y. Wang, C. Liu, and S. Chen, "Protective effects and mechanisms of mogroside V on LPS-induced acute lung injury in mice," Pharmaceutical Biology, vol. 52, no. 6, pp. 729-734, 2014.

[118] M. Akhtar, A. Shaukat, A. Zahoor et al., "Anti-inflammatory effects of Hederacoside-C on Staphylococcus aureus induced inflammation via TLRs and their downstream signal pathway in vivo and in vitro," Microbial Pathogenesis, vol. 137, p. 103767, 2019.

[119] S. Fazio, J. Pouso, D. Dolinsky et al., "Tolerance, safety and efficacy of Hedera helix ${ }^{1}$ extract in inflammatory bronchial diseases under clinical practice conditions: A prospective, open, multicentre postmarketing study in 9657 patients," Phytomedicine, vol. 16, no. 1, pp. 17-24, 2009.

[120] J. Tao, Y. Nie, Y. Hou et al., "Chemomics-integrated proteomics analysis of Jie-Geng-Tang to ameliorate lipopolysaccharideinduced acute lung injury in mice," Evidence-based Complementary and Alternative Medicine, vol. 2016, Article ID 7379146, 12 pages, 2016. 
[121] H. Cui, X. Liu, J. Zhang et al., "Rhodiola rosea L. attenuates cigarette smoke and lipopolysaccharide-induced COPD in rats via inflammation inhibition and antioxidant and antifibrosis pathways," Evidence-based Complementary and Alternative Medicine, vol. 2021, Article ID 6103158, 18 pages, 2021.

[122] N. Yingkun, W. Zhenyu, L. Jing, L. Xiuyun, and Y. Huimin, "Stevioside protects LPS-induced acute lung injury in mice," Inflammation, vol. 36, no. 1, pp. 242-250, 2013.

[123] A. Kandeil, A. Mostafa, O. Kutkat et al., "Bioactive polyphenolic compounds showing strong antiviral activities against severe acute respiratory syndrome coronavirus 2," Pathogens, vol. 10, no. 6, p. 758, 2021.

[124] J.-L. Yu, X. S. Zhang, X. Xue, and R. M. Wang, "Patchouli alcohol protects against lipopolysaccharide-induced acute lung injury in mice," The Journal of Surgical Research, vol. 194, no. 2, pp. 537-543, 2015.

[125] C.-Y. Sun, L. Q. Xu, Z. B. Zhang et al., "Protective effects of pogostone against LPS-induced acute lung injury in mice via regulation of Keap1-Nrf2/NF- $\kappa \mathrm{B}$ signaling pathways," International Immunopharmacology, vol. 32, pp. 55-61, 2016.

[126] S. P. Guan, W. Tee, D. S. W. Ng et al., "Andrographolide protects against cigarette smoke-induced oxidative lung injury via augmentation of Nrf2 activity," British Journal of Pharmacology, vol. 168, no. 7, pp. 1707-1718, 2013.

[127] W. S. D. Tan, W. Liao, H. Y. Peh et al., “Andrographolide simultaneously augments Nrf2 antioxidant defense and facilitates autophagic flux blockade in cigarette smoke-exposed human bronchial epithelial cells," Toxicology and Applied Pharmacology, vol. 360, pp. 120-130, 2018.

[128] D. Yang, W. Zhang, L. Song, and F. Guo, “Andrographolide protects against cigarette smoke-induced lung inflammation through activation of heme oxygenase-1," Journal of Biochemical and Molecular Toxicology, vol. 27, no. 5, pp. 259265, 2013.

[129] K. Jiang, T. Zhang, N. Yin et al., "Geraniol alleviates LPSinduced acute lung injury in mice via inhibiting inflammation and apoptosis," Oncotarget, vol. 8, no. 41, pp. 7103871053, 2017.

[130] V. Vinothkumar, S. Manoharan, G. Sindhu, M. R. Nirmal, and V. Vetrichelvi, "Geraniol modulates cell proliferation, apoptosis, inflammation, and angiogenesis during 7,12dimethylbenz[a]anthracene-induced hamster buccal pouch carcinogenesis," Molecular and Cellular Biochemistry, vol. 369, no. 1-2, pp. 17-25, 2012.

[131] X. Feng and A. Jia, "Protective effect of carvacrol on acute lung injury induced by lipopolysaccharide in mice," Inflammation, vol. 37, no. 4, pp. 1091-1101, 2014.

[132] S. G. Mortazavi Moghaddam, M. Kianmehr, and M. R. Khazdair, "The possible therapeutic effects of some medicinal plants for chronic cough in children," Evidence-based Complementary and Alternative Medicine, vol. 2020, Article ID 2149328, 15 pages, 2020.

[133] W. Yang, D. Qiang, M. Zhang et al., "Isoforskolin pretreatment attenuates lipopolysaccharide-induced acute lung injury in animal models," International Immunopharmacology, vol. 11, no. 6, pp. 683-692, 2011.

[134] Y.-H. Hsieh, J. S. Deng, H. P. Pan, J. C. Liao, S. S. Huang, and G. J. Huang, "Sclareol ameliorate lipopolysaccharide-induced acute lung injury through inhibition of MAPK and induction of HO-1 signaling," International Immunopharmacology, vol. 44, pp. 16-25, 2017.
[135] D. Wei and Z. Huang, “Anti-inflammatory effects of triptolide in LPS-induced acute lung injury in mice," Inflammation, vol. 37, no. 4, pp. 1307-1316, 2014.

[136] M. Boskabady, M. R. Khazdair, R. Bargi et al., "Thymoquinone ameliorates lung inflammation and pathological changes observed in lipopolysaccharide-induced lung injury," Evidence-based Complementary and Alternative Medicine, vol. 2021, Article ID 6681729, 10 pages, 2021.

[137] H. Yang, H. Lv, H. Li, X. Ci, and L. Peng, "Oridonin protects LPS-induced acute lung injury by modulating Nrf2-mediated oxidative stress and Nrf2-independent NLRP3 and NF- $\kappa \mathrm{B}$ pathways," Cell Communication and Signaling: CCS, vol. 17, no. 1, p. 62, 2019.

[138] X.-Y. Chen, Y. X. Dou, D. D. Luo et al., " $\beta$-Patchoulene from patchouli oil protects against LPS-induced acute lung injury via suppressing NF- $\kappa \mathrm{B}$ and activating Nrf2 pathways," International Immunopharmacology, vol. 50, pp. 270-278, 2017.

[139] Z. San, Y. Fu, W. Li et al., "Protective effect of taraxasterol on acute lung injury induced by lipopolysaccharide in mice," International Immunopharmacology, vol. 19, no. 2, pp. 342350, 2014.

[140] J. Remali and W. M. Aizat, "A review on plant bioactive compounds and their modes of action against coronavirus infection," Frontiers in Pharmacology, vol. 11, 2021.

[141] Z. Li, X. Xiao, and M. Yang, "Asiatic acid inhibits lipopolysaccharide-induced acute lung injury in mice," Inflammation, vol. 39, no. 5, pp. 1642-1648, 2016.

[142] W.-Y. Yu, C. X. Gao, H. H. Zhang, Y. G. Wu, and C. H. Yu, "Herbal active ingredients: potential for the prevention and treatment of acute lung injury," BioMed Research International, vol. 2021, Article ID 5543185, 19 pages, 2021.

[143] J. Wang, Y. Nie, Y. Li et al., "Identification of target proteins of mangiferin in mice with acute lung injury using functionalized magnetic microspheres based on click chemistry," Journal of Agricultural and Food Chemistry, vol. 63, no. 45, pp. 10013-10021, 2015.

[144] S. Zhang, L. T. Xu, A. X. Li, and S. M. Wang, "Effects of ergosterol, isolated from Scleroderma polyrhizum pers., on lipopolysaccharide-induced inflammatory responses in acute lung injury," Inflammation, vol. 38, no. 5, pp. 1979-1985, 2015.

[145] Y. Tang, Y. Chen, Z. Chu, B. Yan, and L. Xu, "Protective effect of cryptotanshinone on lipopolysaccharide-induced acute lung injury in mice," European Journal of Pharmacology, vol. 723, pp. 494-500, 2014.

[146] N. Chen, Q. Wu, G. Chi et al., "Prime-O-glucosylcimifugin attenuates lipopolysaccharide-induced acute lung injury in mice," International Immunopharmacology, vol. 16, no. 2, pp. 139-147, 2013.

[147] Z.-Q. Su, Z. Z. Mo, J. B. Liao et al., "Usnic acid protects LPSinduced acute lung injury in mice through attenuating inflammatory responses and oxidative stress," International Immunopharmacology, vol. 22, no. 2, pp. 371-378, 2014.

[148] G.-Z. Bai, H. T. Yu, Y. F. Ni et al., "Shikonin attenuates lipopolysaccharide-induced acute lung injury in mice," The Journal of Surgical Research, vol. 182, no. 2, pp. 303-311, 2013.

[149] D. Liang, Y. Sun, Y. Shen et al., "Shikonin exerts antiinflammatory effects in a murine model of lipopolysaccharideinduced acute lung injury by inhibiting the nuclear factor- kappaB signaling pathway," International Immunopharmacology, vol. 16, no. 4, pp. 475-480, 2013. 
[150] J. Ma, H. Xu, J. Wu, C. Qu, F. Sun, and S. Xu, "Linalool inhibits cigarette smoke-induced lung inflammation by inhibiting NF- $\kappa \mathrm{B}$ activation," International Immunopharmacology, vol. 29, no. 2, pp. 708-713, 2015.

[151] X. Xie, S. Sun, W. Zhong et al., "Zingerone attenuates lipopolysaccharide-induced acute lung injury in mice," International Immunopharmacology, vol. 19, no. 1, pp. 103-109, 2014.

[152] M.-H. Liu, A. H. Lin, H. F. Lee, H. K. Ko, T. S. Lee, and Y. R. Kou, "Paeonol attenuates cigarette smoke-induced lung inflammation by inhibiting ROS-sensitive inflammatory signaling," Mediators of Inflammation, vol. 2014, Article ID 651890, 13 pages, 2014.

[153] W. Jing, M. Chunhua, and W. Shumin, "Effects of acteoside on lipopolysaccharide-induced inflammation in acute lung injury via regulation of NF- $\kappa \mathrm{B}$ pathway in vivo and in vitro," Toxicology and Applied Pharmacology, vol. 285, no. 2, pp. 128-135, 2015.

[154] L. Cheng, F. Li, R. Ma, and X. Hu, "Forsythiaside inhibits cigarette smoke-induced lung inflammation by activation of $\mathrm{Nrf2}$ and inhibition of NF- $\kappa \mathrm{B}$," International Immunopharmacology, vol. 28, no. 1, pp. 494-499, 2015.

[155] J. Langeder, U. Grienke, Y. Chen, J. Kirchmair, M. Schmidtke, and J. M. Rollinger, "Natural products against acute respiratory infections: strategies and lessons learned," Journal of Ethnopharmacology, vol. 248, p. 112298, 2020.

[156] F. P. R. Santana, N. M. Pinheiro, M. I. B. Mernak et al., "Evidences of herbal medicine-derived natural products effects in inflammatory lung diseases," Mediators of Inflammation, vol. 2016, Article ID 2348968, 14 pages, 2016.

[157] L. Wang, S. Li, Y. Yao, W. Yin, and T. Ye, “The role of natural products in the prevention and treatment of pulmonary fibrosis: a review," Food \& Function, vol. 12, no. 3, pp. 9901007, 2021.

[158] M.-Y. Kuo, M. F. Liao, F. L. Chen et al., "Luteolin attenuates the pulmonary inflammatory response involves abilities of antioxidation and inhibition of MAPK and $\mathrm{NF} \kappa \mathrm{B}$ pathways in mice with endotoxin- induced acute lung injury," Food and Chemical Toxicology, vol. 49, no. 10, pp. 2660-2666, 2011.

[159] X. Chen, X. Yang, T. Liu et al., "Kaempferol regulates MAPKs and NF- $\kappa \mathrm{B}$ signaling pathways to attenuate LPS- induced acute lung injury in mice," International Immunopharmacology, vol. 14, no. 2, pp. 209-216, 2012.

[160] R. Chakravarti, R. Singh, A. Ghosh et al., "A review on potential of natural products in the management of COVID-19," RSC Advances, vol. 11, no. 27, pp. 1671116735, 2021.

[161] J. F.-W. Greiner, J. Müller, M. T. Zeuner et al., "1,8-Cineol inhibits nuclear translocation of NF- $\kappa \mathrm{B}$ p 65 and NF- $\kappa \mathrm{B}-$ dependent transcriptional activity," Biochimica et Biophysica Acta (BBA) - Molecular Cell Research, vol. 1833, no. 12, pp. 2866-2878, 2013.

[162] H. W. Ryu, S. U. Lee, S. Lee et al., "3-Methoxy-catalposide inhibits inflammatory effects in lipopolysaccharide- stimulated RAW264.7 macrophages," Cytokine, vol. 91, pp. 5764, 2017.

[163] M. Omrani, M. Keshavarz, S. Nejad Ebrahimi et al., "Potential natural products against respiratory viruses: a perspective to develop anti-COVID-19 medicines," Frontiers in Pharmacology, vol. 11, 2021.
[164] A. Tiwari, K. R. Mahadik, and S. Y. Gabhe, "Piperine: a comprehensive review of methods of isolation, purification, and biological properties," Medicine in Drug Discovery, vol. 7, p. 100027, 2020.

[165] E. L. Wightman, J. L. Reay, C. F. Haskell, G. Williamson, T. P. Dew, and D. O. Kennedy, "Effects of resveratrol alone or in combination with piperine on cerebral blood flow parameters and cognitive performance in human subjects: a randomised, double-blind, placebo-controlled, cross-over investigation," The British Journal of Nutrition, vol. 112, no. 2, pp. 203213, 2014.

[166] I.-U. Haq, M. Imran, M. Nadeem, T. Tufail, T. A. Gondal, and M. S. Mubarak, "Piperine: a review of its biological effects," Phytotherapy Research, vol. 35, no. 2, pp. 680-700, 2021.

[167] U. Aswar, S. Shintre, S. Chepurwar, and M. Aswar, "Antiallergic effect of piperine on ovalbumin-induced allergic rhinitis in mice," Pharmaceutical Biology, vol. 53, no. 9, pp. 13581366, 2015.

[168] S. Khawas, G. Nosálová, S. K. Majee et al., “In vivo cough suppressive activity of pectic polysaccharide with arabinogalactan type II side chains of Piper nigrum fruits and its synergistic effect with piperine," International Journal of Biological Macromolecules, vol. 99, pp. 335-342, 2017.

[169] C. R. Pradeep and G. Kuttan, "Effect of piperine on the inhibition of lung metastasis induced B16F-10 melanoma cells in mice," Clinical \& Experimental Metastasis, vol. 19, no. 8, pp. 703-708, 2002.

[170] Y. Panahi, M. Ghanei, A. Hajhashemi, and A. Sahebkar, "Effects of curcuminoids-piperine combination on systemic oxidative stress, clinical symptoms and quality of life in subjects with chronic pulmonary complications due to sulfur mustard: a randomized controlled trial," Journal of Dietary Supplements, vol. 13, no. 1, pp. 93-105, 2016.

[171] Z. Wang, Q. Xia, X. Liu et al., "Phytochemistry, pharmacology, quality control and future research of Forsythia suspensa (Thunb.) Vahl: A review," Journal of Ethnopharmacology, vol. 210, pp. 318-339, 2018.

[172] X. Zheng, Y. Fu, S. S. Shi et al., "Effect of forsythiaside A on the RLRs signaling pathway in the lungs of mice infected with the influenza A virus FM1 strain," Molecules, vol. 24, no. 23, p. 4219, 2019.

[173] A. Matkowski, P. Kuś, E. Góralska, and D. Woźniak, "Mangiferin - a bioactive xanthonoid, not only from mango and not just antioxidant," Mini Reviews in Medicinal Chemistry, vol. 13, no. 3, pp. 439-455, 2013.

[174] F. Luo, Q. Lv, Y. Zhao et al., "Quantification and purification of mangiferin from Chinese mango (Mangifera indica L.) cultivars and its protective effect on human umbilical vein endothelial cells under $\mathrm{H}_{2} \mathrm{O}_{2}$-induced stress," International Journal of Molecular Sciences, vol. 13, no. 9, pp. 1126011274, 2012.

[175] G. L. P. Andreu, R. Delgado, J. A. Velho, C. Curti, and A. E. Vercesi, "Mangiferin, a natural occurring glucosyl xanthone, increases susceptibility of rat liver mitochondria to calciuminduced permeability transition," Archives of Biochemistry and Biophysics, vol. 439, no. 2, pp. 184-193, 2005.

[176] E. V. Fomenko and Y. Chi, "Mangiferin modulation of metabolism and metabolic syndrome," BioFactors, vol. 42, no. 5, pp. 492-503, 2016.

[177] X. Gong, L. Zhang, R. Jiang, M. Ye, X. Yin, and J. Wan, “Antiinflammatory effects of mangiferin on sepsis-induced lung injury in mice via up-regulation of heme oxygenase-1," The 
Journal of Nutritional Biochemistry, vol. 24, no. 6, pp. 11731181, 2013.

[178] A. B. Vieira, L. P. Coelho, D. B. R. Insuela et al., "Mangiferin prevents guinea pig tracheal contraction via activation of the nitric oxide-cyclic GMP pathway," PLoS One, vol. 8, no. 8, article e71759, 2013.

[179] H.-W. Guo, C. X. Yun, G. H. Hou et al., "Mangiferin attenuates Th1/Th2 cytokine imbalance in an ovalbumin-induced asthmatic mouse model," PLoS One, vol. 9, no. 6, article e100394, 2014

[180] C. H. Piao, Y. J. Fan, T. V. Nguyen, C. H. Song, and O. H. Chai, "Mangiferin alleviates ovalbumin-induced allergic rhinitis via Nrf2/HO-1/NF- $\kappa \mathrm{B}$ signaling pathways," International Journal of Molecular Sciences, vol. 21, no. 10, p. 3415, 2020.

[181] H. S. Bhatia, E. Candelario-Jalil, A. C. P. de Oliveira, O. A. Olajide, G. Martínez-Sánchez, and B. L. Fiebich, "Mangiferin inhibits cyclooxygenase- 2 expression and prostaglandin $\mathrm{E}_{2}$ production in activated rat microglial cells," Archives of Biochemistry and Biophysics, vol. 477, no. 2, pp. 253-258, 2008.

[182] S. Matsui, H. Matsumoto, Y. Sonoda et al., "Glycyrrhizin and related compounds down-regulate production of inflammatory chemokines IL- 8 and eotaxin 1 in a human lung fibroblast cell line," International Immunopharmacology, vol. 4, no. 13, pp. 1633-1644, 2004.

[183] H.-Y. Park, S. H. Park, H. K. Yoon, M. J. Han, and D. H. Kim, "Anti-allergic activity of 18beta-glycyrrhetinic acid-3-Obeta-D-glucuronide," Archives of Pharmacal Research, vol. 27, no. 1, pp. 57-60, 2004.

[184] J. Cinatl, B. Morgenstern, G. Bauer, P. Chandra, H. Rabenau, and H. W. Doerr, "Glycyrrhizin, an active component of liquorice roots, and replication of SARS- associated coronavirus," Lancet, vol. 361, no. 9374, pp. 2045-2046, 2003.

[185] J. Chrzanowski, A. Chrzanowska, and W. Graboń, "Glycyrrhizin: an old weapon against a novel coronavirus," Phytotherapy Research, vol. 35, no. 2, pp. 629-636, 2021.

[186] G. Cherry, J. Rocke, M. Chu et al., "Loss of smell and taste: a new marker of COVID-19? Tracking reduced sense of smell during the coronavirus pandemic using search trends," Expert Review of Anti-Infective Therapy, vol. 18, no. 11, pp. 1165-1170, 2020.

[187] W. P. Lao, S. A. Imam, and S. A. Nguyen, "Anosmia, hyposmia, and dysgeusia as indicators for positive SARS-CoV-2 infection," World Journal of Otorhinolaryngology - Head and Neck Surgery, vol. 6, Supplement 1, pp. S22-S25, 2020.

[188] Y. Xu and L. Liu, "Curcumin alleviates macrophage activation and lung inflammation induced by influenza virus infection through inhibiting the NF- $\kappa \mathrm{B}$ signaling pathway," Influenza and Other Respiratory Viruses, vol. 11, no. 5, pp. 457-463, 2017.

[189] D. Lelli, A. Sahebkar, T. P. Johnston, and C. Pedone, "Curcumin use in pulmonary diseases: state of the art and future perspectives," Pharmacological Research, vol. 115, pp. 133-148, 2017.

[190] V. K. Soni, A. Mehta, Y. K. Ratre et al., "Curcumin, a traditional spice component, can hold the promise against COVID-19?," European Journal of Pharmacology, vol. 886, p. 173551, 2020

[191] B. Ahmad, M. U. Rehman, I. Amin et al., "A review on pharmacological properties of zingerone (4-(4-hydroxy-3-methox- yphenyl)-2-butanone)," Scientific World Journal, vol. 2015, article 816364, 6 pages, 2015.

[192] J. Wu, W. Peng, R. Qin, and H. Zhou, “Crataegus pinnatifida: chemical constituents, pharmacology, and potential applications," Molecules, vol. 19, no. 2, pp. 1685-1712, 2014.

[193] J. Wang, Y. D. Yue, H. Jiang, and F. Tang, "Rapid screening for flavone C-glycosides in the leaves of different species of bamboo and simultaneous quantitation of four marker compounds by HPLC-UV/DAD," International Journal of Analytical Chemistry, vol. 2012, Article ID 205101, 8 pages, 2012.

[194] D. Zielinska, D. Szawara-Nowak, A. Ornatowska, and W. Wiczkowski, "Use of cyclic voltammetry, photochemiluminescence, and spectrophotometric methods for the measurement of the antioxidant capacity of buckwheat sprouts," Journal of Agricultural and Food Chemistry, vol. 55, no. 24, pp. 9891-9898, 2007.

[195] I. L. Gadioli, M. . S. B. da Cunha, M. V. O. de Carvalho, A. M. Costa, and L. L. O. Pineli, "A systematic review on phenolic compounds in Passiflora plants: exploring biodiversity for food, nutrition, and popular medicine," Critical Reviews in Food Science and Nutrition, vol. 58, no. 5, pp. 785-807, 2018.

[196] E. Tanus-Rangel, S. R. Santos, J. C. S. Lima et al., “Topical and systemic anti-inflammatory effects of Echinodorus macrophyllus (Kunth) Micheli (Alismataceae)," Journal of Medicinal Food, vol. 13, no. 5, pp. 1161-1166, 2010.

[197] D. Hou, L. Yousaf, Y. Xue et al., "Mung bean (Vigna radiata L.): bioactive polyphenols, polysaccharides, peptides, and health benefits," Nutrients, vol. 11, no. 6, p. 1238, 2019.

[198] H.-F. Xue, Z. M. Ying, W. J. Zhang, Y. H. Meng, X. X. Ying, and T. G. Kang, "Hepatic, gastric, and intestinal first-pass effects of vitexin in rats," Pharmaceutical Biology, vol. 52, no. 8, pp. 967-971, 2014.

[199] Z. Zhai, S. E. Gomez-Mejiba, M. S. Gimenez et al., "Free radical-operated proteotoxic stress in macrophages primed with lipopolysaccharide," Free Radical Biology \& Medicine, vol. 53, no. 1, pp. 172-181, 2012. 